\title{
The impact of anorexigenic peptides in experimental models of Alzheimer's disease pathology
}

\author{
Lenka Maletínská1, Andrea Popelová1, Blanka Železná1, Michal Bencze1,2 and Jaroslav Kuneš1,2 \\ ${ }^{1}$ Institute of Organic Chemistry and Biochemistry AS CR, Prague, Czech Republic \\ IInstitute of Physiology AS CR, Prague, Czech Republic
}

Correspondence should be addressed to J Kuneš: kunes@biomed.cas.cz

\begin{abstract}
Alzheimer's disease (AD) is the most prevalent neurodegenerative disorder in the elderly population. Numerous epidemiological and experimental studies have demonstrated that patients who suffer from obesity or type 2 diabetes mellitus have a higher risk of cognitive dysfunction and AD. Several recent studies demonstrated that food intakelowering (anorexigenic) peptides have the potential to improve metabolic disorders and that they may also potentially be useful in the treatment of neurodegenerative diseases. In this review, the neuroprotective effects of anorexigenic peptides of both peripheral and central origins are discussed. Moreover, the role of leptin as a key modulator of energy homeostasis is discussed in relation to its interaction with anorexigenic peptides and their analogs in AD-like pathology. Although there is no perfect experimental model of human AD pathology, animal studies have already proven that anorexigenic peptides exhibit neuroprotective properties. This phenomenon is extremely important for the potential development of new drugs in view of the aging of the human population and of the significantly increasing incidence of $A D$.
\end{abstract}

\author{
Key Words \\ - Alzheimer's disease \\ pathology \\ - experimental rodent \\ models \\ - leptin \\ - anorexigenic \\ neuropeptides
}

\section{Introduction}

A major problem in developed countries is that, although longevity has increased, the incidence of several so-called diseases of civilization is increasing simultaneously. Neurodegenerative diseases, obesity, type 2 diabetes mellitus (T2DM), hypertension and other diseases are profound examples of this tendency. Obesity, as well as Alzheimer's disease (AD), directly affects millions of adults each year and results in health care costs in the billions of dollars range. It is estimated that care for AD patients costs USA $\$ 214$ billion a year, and this will grow up approximately to $\$ 1.2$ trillion in 2050 (Kim \& Feldman 2015). Moreover, on the basis of WHO estimations for developed countries it is evident that the number of affected people by dementia including $\mathrm{AD}$ will double every 20 years to 81.1 million by 2040 (Ferri et al. 2005). Despite many advances in understanding of the etiology of all above-mentioned diseases, there is still no effective therapy for both these problems.

It has been suggested that some food intake-regulating peptides could be promising candidates for obesity and T2DM treatment (Maletinska et al. 2015, van der Klaauw 2018) and may also alleviate the cognitive deficits of neurodegenerative disorders (Giuliani et al. 2017, Holscher 2018, Mandal et al. 2018). Anorexigenic peptides lower food intake, while orexigenic peptides increase it. In the hypothalamus and hindbrain, these peptides act to 
affect the feelings of hunger and satiety (Kunes et al. 2016, Andermann \& Lowell 2017). These peptides are released not only in various parts of the central nervous system (CNS), mainly in the hypothalamus and brainstem (such as anorexigenic cocaine- and amphetamine-regulated transcript peptide, melanocortins or prolactin-releasing peptide and orexigenic neuropeptide $\mathrm{Y}$ or orexins), but also in the periphery (such as anorexigenic leptin, glucagon-like peptide and cholecystokinin and orexigenic ghrelin) (Fig. 1), and they all act centrally to regulate energy homeostasis (Spiegelman \& Flier 2001, Frago \& Chowen 2015, Prinz \& Stengel 2017). Although many of these peptides have been known for a relatively long time, their mechanism of action and their interactions are still poorly understood. For example, in obese animals, the regulation of food intake and energy expenditure does not function properly; the levels of hormones responsible for the feeling of satiety are high, but their effect on the target tissue is compromised (Cui et al. 2017).

Moreover, a major problem associated with natural peptides is their low stability in the organism and their difficulty in crossing the blood-brain barrier (BBB) after peripheral application. Proposed solutions (e.g. lipidization) to these problems were summarized in several papers (Malavolta \& Cabral 2011, Ahrens et al. 2012, Kunes et al. 2016).

$\mathrm{AD}$ is the most common cause of progressive dementia in the elderly population and is increasing in incidence (Nitrini et al. 2009, Curiati et al. 2014). AD is histologically characterized by the accumulation of amyloid- $\beta$ protein (A $\beta)$ as extracellular plaques and by the deposition of hyperphosphorylated tau protein in intracellular neurofibrillary tangles (NFT). Although several biomarkers for specific phases of $\mathrm{AD}$ have been described, a definitive diagnosis requires postmortem brain autopsy (Cummings 2011, Humpel 2011). It was demonstrated that lifestyle factors as well as the symptoms of metabolic syndrome (MetS), such as obesity, hypertension or glucose intolerance, play a critical role in the onset of dementia and $\mathrm{AD}$ as well as in their progression (Lara et al. 2013). To date, MetS has received relatively little attention as a risk factor for $\mathrm{AD}$ because epidemiological studies have not produced unambiguous results.

The objective of this review is to summarize current information on the potential neuroprotective properties of food intake-lowering (anorexigenic) peptides that have been tested in experimental models of AD-like pathology. We wish to speculate about the central integrative role of leptin, an adipose-derived anorexigenic protein that plays a key role in energy homeostasis, in these effects.

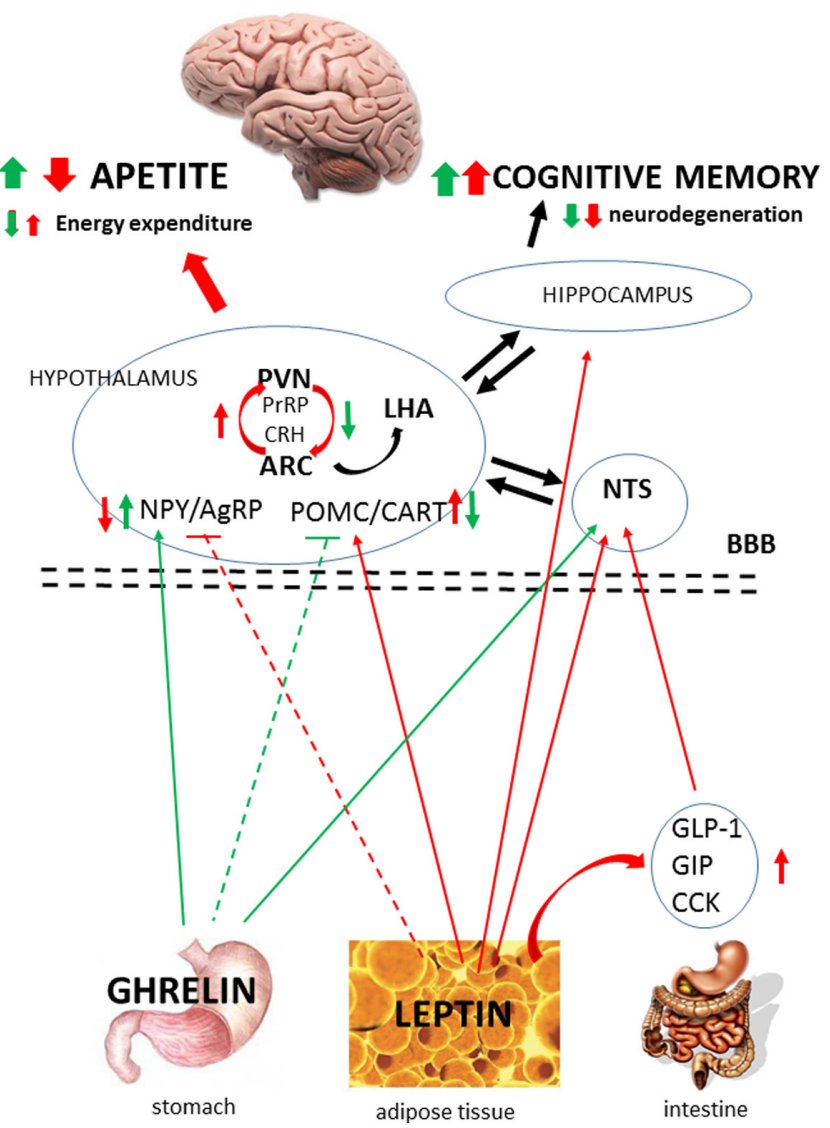

Figure 1

The interaction between leptin, ghrelin and food intake regulating peptides. Leptin, hormone produced in adipose tissue, increases expression of anorexigenic (food intake lowering) and decreases expression of orexigenic (appetite stimulating) peptides, both in the brain and in the periphery (red arrows). Contrary, ghrelin, hormone produced in stomach, increases expression of orexigenic and decreases expression of anorexigenic peptides in brain (green arrows). In the periphery, leptin increases expression of glucagon-like peptide 1 (GLP-1), glucosedependent insulinotropic polypeptide (GIP) and cholecystokinin (CCK) produced by intestine. In the brain centers connected to food intake regulation which are solitary tract nucleus (NTS) in the brainstem and nucleus arcuatus (Arc), paraventricular nucleus (PVN) and lateral hypothalamic area in the hypothalamus, leptin increases and ghrelin decreases production of anorexigenic proopiomelanocortin (POMC), cocaine- and amphetamine-regulated transcript (CART) peptide, prolactin-releasing peptide (PrRP) and corticotropin-releasing hormone $(\mathrm{CRH})$. On the contrary, leptin decreases and ghrelin increases expression of orexigenic hormones neuropeptide Y (NPY) and agouti-related peptide. Thus, leptin causes decreased appetite and increased energy expenditure and ghrelin acts as physiological antagonist in these processes. However, both leptin and ghrelin were shown to decrease neurodegenerative processes in the brain, mainly in hippocampus which is the center of memory formation and learning.

Accumulating evidence has indicated an association between higher serum leptin levels and lower frequency of dementia and/or mild cognitive impairment in women with normal body mass index (Zeki Al Hazzouri et al. 2013), suggesting that leptin might be a better predictor 
of dementia than traditional anthropometric measures such as height, weight and body mass index. Blood leptin levels were found to be negatively related to the incidence of dementia and AD (Lieb et al. 2009) and higher blood leptin level was suggested to be protective against cognitive decline and $\mathrm{AD}$ development (Holden et al. 2009). However, attenuated leptin concentrations were found in CSF and hippocampal tissue of AD patients (Bonda et al. 2014). Regarding brain leptin, leptin mRNA was undetectable in both neocortex and hippocampus of APP/PS1 mice and their WT controls until 18 months of age. It shows that leptin in both healthy and AD-like brain is not expressed in the brain areas connected with cognitive memory (King et al. 2018). However, agedependent $A \beta$ levels in the brain areas mentioned were linked to disturbed leptin signaling (King et al. 2018).

\section{MetS as a risk factor for AD}

Metabolic syndrome (MetS), also known as insulin resistance syndrome, was first described by Barker (Barker et al. 1993). In general, MetS is a cluster of common symptoms involving several vascular risk factors combining obesity, dyslipidemia, insulin resistance, glucose intolerance and arterial hypertension (Ricci et al. 2017). Together with obesity and insulin resistance, MetS increases the probability of development of $\mathrm{AD}$ and other neurodegenerative diseases in the elderly (Razay et al. 2007, Raffaitin et al. 2009).

Interestingly, a meta-analysis of the relationship between MetS and cognitive function clearly demonstrated the association between MetS and longitudinal changes in cognitive function (Siervo et al. 2014). The authors analyzed 13 studies, with a total sample size of 19,522 subjects. Although a small association of MetS with cognitive decline was observed, a marginal significant association was observed in the younger old group after age-stratification. These results emphasize the importance of age-stratified risk prediction models of dementia in subjects with chronic metabolic disorders.

\section{Type 2 diabetes mellitus (T2DM)}

It was demonstrated in epidemiological studies that patients with T2DM have a higher incidence of $\mathrm{AD}$ (Vagelatos \& Eslick 2013, Ricci et al. 2017). T2DM is a serious metabolic and endocrine disorder that is characterized by resistance to the effects of insulin in the periphery, leading to increased glucose levels in the blood. One of the

(c) 2019 Society for Endocrinology Published by Bioscientifica Ltd.
Printed in Great Britain major risk factors for T2DM development is obesity that contributes to the development of insulin resistance through several mechanisms including increased plasma concentrations of free fatty acids leading to impaired $\beta$-cell function, increased levels of pro-inflammatory cytokines such as tumor necrosis factor $\alpha$ (TNF- $\alpha$ ), interleukin 6 (IL-6) and disturbances in hormone levels (increased levels of glucagon and leptin, decreased level of adiponectin) (Liu et al. 2016). Furthermore, it was discovered that T2DM and $\mathrm{AD}$ share several molecular processes that underlie the degenerative developments that occur in these two conditions. Disturbances in insulin signaling appear to be the main common impairment that affects cell growth and differentiation, cellular repair mechanisms, energy metabolism and glucose utilization. Insulin not only regulates blood glucose levels but also acts as a growth factor on all cells, including neurons in the CNS (Pomytkin et al. 2018).

Impairment of insulin signaling therefore not only affects blood glucose levels but also causes numerous degenerative processes. Other growth factors involved in signaling systems, such as insulin-like growth factors (IGFs) and transforming growth factors, are also impaired in both conditions (Li \& Holscher 2007). Based on the similarity of these mechanisms, $\mathrm{AD}$ has been referred to as 'type 3 diabetes' (Steen et al. 2005, de la Monte 2014).

\section{Type 3 diabetes}

The concept that $\mathrm{AD}$ represents type 3 diabetes is supported by a number of findings. It was demonstrated that cerebral glucose utilization and energy metabolism worsen with the progression of cognitive impairment. This result could be related to impairment of insulin and IGF expression in $\mathrm{AD}$ because insulin/IGF receptor binding is reduced (de la Monte et al. 2006). The cited work demonstrates extensive impairment in insulin and IGF type I and II (IGF-I and IGF-II) signaling mechanisms in brains with $\mathrm{AD}$.

In the CNS, insulin is required for neuronal synaptic and dendritic plasticity, for learning, and for memory formation triggered through the activation of extracellular signal-regulated kinase 1/2 (ERK1/2) (Dineley et al. 2014). It was discovered that aging causes a significant decrease in insulin receptor (IR) number and in the concentration of insulin itself, thus leading to impaired insulin signaling and memory deficits in elderly people (Dineley et al. 2014, Velazquez et al. 2017).

As shown in Fig. 2, in physiological condition, insulin binds to the IR which cause autophosphorylation of the 


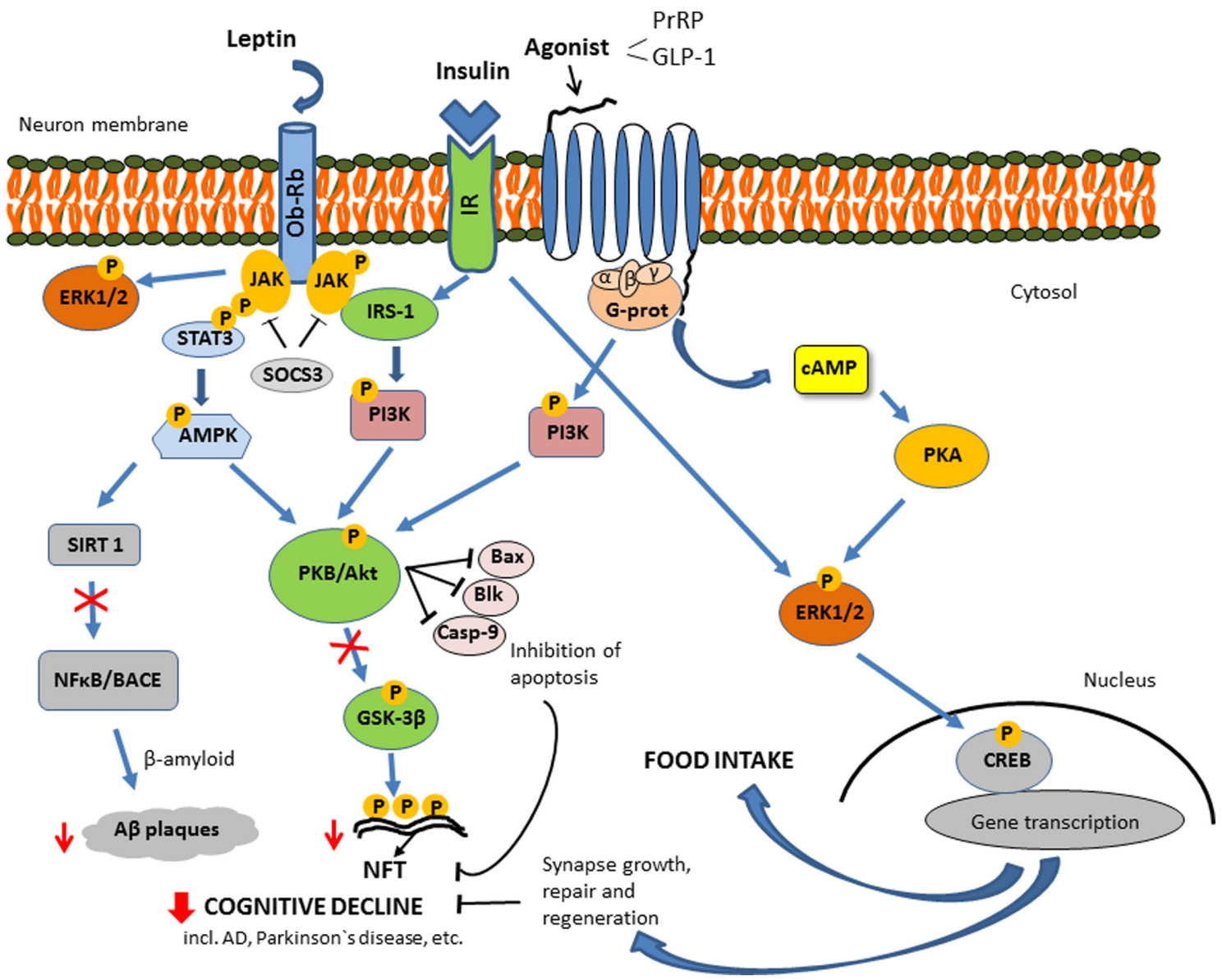

Figure 2

Scheme of potential neuroprotective effects of anorexigenic peptides. Activation of leptin receptor (ObRb), insulin receptor (IR), prolactin-releasing peptide (PrRP) and glucagon-like peptide 1 (GLP-1) receptors by their natural or synthetic analogs activate the signaling pathways with potential neuroprotective effect including the IRS-1/PI3/Akt pathway which further resulted in inhibition of apoptosis and increased phosphorylation of glycogen

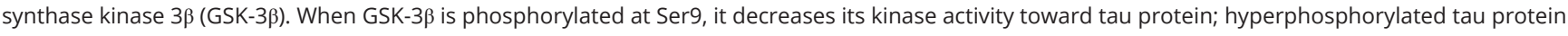
forms neurofibrillary tangles (NFT). Moreover, leptin activates Janus activated kinase 2 (JAK2) that phosphorylates signal transducer and activator of transcription 3 (STAT3) that can activate sirtuin 1 (SIRT1) and further blocks production of A $\beta$ plaques by inhibiting nuclear factor-k $\beta$ (NFk $\beta$ ) and betasecretase 1 (BACE). Suppressor of cytokine signaling 3 (SOCS3) interfere with leptin receptor signal transduction. For memory formation, neuronal synaptic and dendritic plasticity, the activation of extracellular signal-regulated kinase 1/2 (ERK1/2) and cAMP response element-binding protein (CREB) is required. ERK1/2 can be activated by leptin, insulin and through G-protein coupled receptors that activates protein kinase A (PKA) through increased level of CAMP.

tyrosine kinase domain of the IR which subsequently trigger activation of other kinases, such as insulin receptor substrate 1 (IRS-1), regulatory subunit of phosphoinositide 3 kinase (PI3K) p85 or Akt. Activated Akt phosphorylates glycogen synthase kinase $3 \beta$ (GSK-3 $\beta$ ) at Ser9, thereby inhibiting the kinase activity of GSK-3 (Liu et al. 2011). Besides insulin, leptin contributes to activation of Akt and reversely, leptin resistance results in a lowered Akt activation (Fig. 2). In old APP/PS1 mice, a decrease in Akt activation through an increase in suppressor of cytokine signaling (SOCS3) was linked to an inefficient leptin signaling (King et al. 2018).

Thus, in central insulin resistance, activation of the insulin signaling cascade is impaired;

(C) 2019 Society for Endocrinology Published by Bioscientifica Ltd. Printed in Great Britain this outcome is manifested by decreased phosphorylation of the implicated kinases and finally by decreased phosphorylation of GSK-3 $\beta$ at Ser9, its inhibitory site. This decreased phosphorylation leads to GSK-3 $\beta$ activation. GSK-3 $\beta$ is one of the most important kinases implicated in the hyperphosphorylation of tau (Dineley et al. 2014). GSK-3 $\beta$ kinase can be phosphorylated by AMP-activated protein kinase (AMPK) that is in the brain - unlike the periphery - inhibited though leptin signaling, which is as it was shown in neuronal cells (Greco et al. 2009). Insulin resistance could result from improper leptin signaling as shown in Fig. 2. In db/db mouse with nonfunctional leptin receptor, a model of spontaneous T2DM with obesity, hyperinsulinemia, hyperglycemia 
and hypothermia, neuronal Tau hyperphosphorylation was determined (El Khoury et al. 2016). Therefore, leptin was qualified as a potent $\mathrm{AD}$ therapeutics Tezapsidis et al. 2009).

Central insulin resistance could be partly caused by increased level of pro-inflammatory cytokines, e.g. TNF- $\alpha$ (Ferreira et al. 2014). TNF- $\alpha$ is produced in brain by microglia or can penetrate to brain through $\mathrm{BBB}$ from the periphery where it is produced by adipocytes, as described earlier. TNF- $\alpha$ triggers pro-apoptotic c-Jun N-terminal kinase (JNK), which further impairs activation of insulin signaling cascade by increased phosphorylation of IRS-1 at inhibitory Ser epitopes (Ferreira et al. 2014).

Because of the newly discovered link between T2DM and $\mathrm{AD}$, a possible new strategy for the prevention and treatment of neurodegenerative diseases has emerged. It is hypothesized that agents that increase insulin sensitivity could ameliorate insulin function in the CNS and could thus be used as effective treatments for $\mathrm{AD}$. The potential neuroprotective properties of many anorexigenic and/or insulin-sensitizing peptides are described later in this review, but here it should be mentioned that two anti-diabetic drugs that are analogs of the incretin hormone glucagon-like peptide 1 (GLP-1), liraglutide (Victoza, NovoNordisk) and exendin-4 (Byetta, AstraZeneca), were proven in several animal models of $\mathrm{AD}$ to significantly improve memory, decreased $\mathrm{A} \beta$ plaque load in hippocampus or reduce neuroinflammation; thus, these promising compounds were tested in clinical trials (https://clinicaltrials.gov/ct2/show/NCT01255163; Holscher 2018).

\section{The relationship between insulin resistance and AD}

Insulin resistance generally refers to a condition in which tissues do not respond properly to physiological concentrations of insulin, leading to hyperinsulinemia, hyperglycemia and hyperlipidemia (Turner \& Heilbronn 2008). These symptoms drive MetS and diseases such as T2DM, obesity and chronic inflammation. In the brain, in addition to glucose utilization, insulin supports neuronal functions including synaptogenesis, synaptic remodeling and modulation of neurotransmitter function (Cholerton et al. 2011). Insulin resistance may induce metabolic stress and may cause mitochondrial dysfunction and chronic inflammation that further exacerbates $A \beta$ clearance and metabolism (Farris et al. 2003). It was shown that at the subcellular level, oxidative damage caused by

(c) 2019 Society for Endocrinology Published by Bioscientifica Ltd. Printed in Great Britain increased production of reactive oxygen species (ROS) leads to mitochondrial dysfunction in both preclinical $\mathrm{AD}$ models and in persons with the disease (Butterfield et al. 2014, Wang et al. 2014). Elevated oxidative stress is detectable by increases in the levels of lipid peroxides, 8-oxoguanine and oxidized proteins (Pugazhenthi et al. 2017, Reddy \& Reddy 2017). Moreover, oxidative stress increases $\mathrm{A} \beta$ production in vitro and in vivo (Wang et al. 2014).

The molecular mechanisms of insulin activity in the brain include the PI3K/Akt pathway and the Ras/mitogenactivated protein kinase (MAPK) pathways, activation of both of them is decreased which is manifested by decreased phosphorylation of kinases implicated in the signaling cascades (Ghasemi et al. 2014, Guillot et al. 2016). Insulin signaling, which regulates glucose utilization in the brain, modulates acetylcholine levels and $A \beta$ levels in the brain. Therefore, impaired activation of insulin signaling pathway can affect cognition in AD (Schioth et al. 2012, Li et al. 2018). In the brains of AD patients, a progressive neuronal dysfunction, a loss of neurons and synaptic connections, increased neuroinflammation, together with increased level of $A \beta$ forming extracellular senile plaques, as well as vascular deposits and the hyperphosphorylated tau protein forming pathological intracellular NFT are observed (Cummings et al. 1998, Graham et al. 2017). Interestingly, $\mathrm{A} \beta$ accumulation in the brain has been shown to induce both brain and peripheral insulin resistance in animal studies (Donev et al. 2009, Bharadwaj et al. 2017). Thus, insulin resistance and impaired insulin signaling can contribute to the pathophysiological alterations observed in $\mathrm{AD}$ because insulin signaling is involved in tau phosphorylation and $A \beta$ metabolism. However, it has also been demonstrated that $A \beta$ oligomers can bind to insulin receptors, triggering their internalization, decreasing their neuronal responsiveness to insulin and promoting insulin resistance (Xie et al. 2002). Thus, it could be argued that $\mathrm{A} \beta$ is a convergent factor in the development of both pathologies.

\section{Experimental models and methods used to study neurodegeneration}

\section{Animal models}

To better understand the etiology of $\mathrm{AD}$, appropriate experimental models are needed. The models most frequently used in the study of neurodegeneration are transgenic mouse models with $A \beta$ and/or tau pathology. However, no animal model recapitulates the entirety of 
$\mathrm{AD}$ in humans; therefore, it is important to understand both the utility and the limitations of particular animal models (Jankowsky \& Zheng 2017). Most AD mouse models are representative of FAD, which accounts for only a small percentage of the total $\mathrm{AD}$ cases that are diagnosed each year. Each transgenic mouse model of $\mathrm{AD}$ provides different insights into aspects of $\mathrm{AD}$ pathogenesis and the cognitive deficits associated with the disease. The most frequently used mouse models contain APP and PS1 mutations or APP/PS1/tau mutations (also known as the 3xTg AD mouse model) (reviewed in Webster et al. 2014). The APP/PS1 model with the Swedish mutation of APP is the most widely used model; the first reported impairment in spatial working memory as well as $\mathrm{A} \beta$ pathology was observed using 6-month-old animals (Trinchese et al. 2004), and this model is most commonly used to test potential neuroprotective features of new compounds, including anorexigenic neuropeptides. In APP/PS1 mouse models, decreased neurogenesis has been repeatedly reported to be associated with further AD-typical pathological hallmarks such as extracellular $A \beta$ plaque deposition, behavioral deficits and neuroinflammation. This model is a wellcharacterized AD model of amyloidosis, and for some of its neuropathological characteristics, this model most closely resembles the early stages of human AD (Price et al. 2000, Kreiner 2018).

Several transgenic mouse models of tau pathology have been created and characterized (reviewed Gotz et al. 2007, Hochgrafe et al. 2013, Dujardin et al. 2015). The tau models have been used to unravel the pathophysiology of $\mathrm{AD}$, to search for disease modifiers and to develop novel treatment strategies. However, these models have very rarely been used to test new potential neuroprotective compounds, although such studies could be very valuable. Moreover, the existence of a number of neurodegenerative diseases featuring tau pathology in the absence of $A \beta$ extracellular deposits underscores the relevance of research on tau (Gotz et al. 2007).

Rat and mouse models of obesity/diabetes develop neurodegeneration with age. Obesity can be caused by genetic mutations in the leptin receptor or by feeding animals a diet with a high percentage of fat, so-called models of diet-induced obesity (DIO). A research using animal models identified mechanisms that are shared by diabetes and AD (Crews et al. 2010, Park 2011, Cavanaugh et al. 2014). Some models exploit the exogenous application of streptozotocin (STZ), which disrupts insulin secretion, resulting in disrupted brain insulin signaling and increased tau pathology (Shi et al. 2017b).

(c) 2019 Society for Endocrinology Published by Bioscientifica Ltd. Printed in Great Britain
Ablation of the nucleus arcuatus (Arc) by monosodium glutamate, resulting in dysregulation of energy homeostasis or non-functional leptin signaling with aging, also leads to increased tau pathology (Spolcova et al. 2014, 2015).

Finally, a very specific model of accelerated aging, the senescence-accelerated mouse prone 8 mouse (SAMP8), was developed in the Takeda laboratory (Takeda et al. 1981) and is now widely used as a model of spontaneously occurring aging. SAMP8 mice display several neurodegenerative features including $A \beta$ pathology, tau pathology, impairment of memory and synaptic plasticity and disruption of BBB function (Morley et al. 2012, Akiguchi et al. 2017). This model is very complex because of polygenic character of neurodegenerative changes and is very useful for the testing of new potentially neuroprotective compounds.

\section{Behavioral tests}

The most frequently used behavioral tests include spatial memory tests that test long-term (MWM, radial arm water maze, Barnes maze) or short-term memory (Y-maze or T-maze), associative learning tasks (passive avoidance, fear conditioning) and recognition memory tasks (novel object recognition - NOR) (Webster et al. 2014). Although the MWM might appear to be the most robust of these tests (high motivation of animals to perform and low olfactory cue bias), high test-induced stress (Harrison et al. 2009) might influence the results of further biochemical and molecular analyses. It is even more important to consider this possibility in experiments with obese models because of changed mobility and motivation of obese animals (Friend et al. 2017). Other behavioral tests such as the Barnes maze can be less stressful for the mice, but they are not always easy to conduct due to lack of motivation. When testing different animal models, individual adjustments to the test protocols may be necessary.

All the animal studies that have been described in the literature have limitations. First, the investigation is sometimes not long enough, especially when the feeding of a high-fat diet is involved. Second, there are some problems associated with investigating potential cognitive deficits in working memory or measurement of anxiety (Walker \& Harrison 2015). No animal model can mimic the entire range of symptoms that occur in human $\mathrm{AD}$, and there is still a need to clearly define behavioral test/s for individual neurodegenerative diseases, including AD. Therefore, the results obtained from animal models with the intention of applying them to human AD should be drawn from several behavioral tests. 


\section{Cellular hallmarks of AD}

$A \beta$ senile plaques are formed by aggregated $A \beta$ peptides that differ in length and contain 42-43 amino acids residues. $A \beta$ originates from APP, a transmembrane protein. The main function of APP is not precisely known, but in the CNS, it has a positive effect on synapse formation and plasticity, neural activity and memory (Turner et al. 2003, Priller et al. 2006). However, under pathophysiological conditions, APP is processed in the amyloidogenic pathway; in this pathway, APP is cleaved by $\beta$ - and $\gamma$-secretases resulting in the formation of $A \beta$ chain 42-43 amino acids that form toxic oligomers. The $\mathrm{A} \beta$ chains polymerize into fibrils and are finally stored as senile plaques (Tabaton et al. 2010).

Tau belongs to the family of microtubule-associated proteins. This protein promotes the assembly of tubulin into microfilaments and helps stabilize the microtubules and thus stabilize the axons of neurons (Weingarten et al. 1975). For proper tau function, the phosphorylation state of tau is crucial; aberrant tau phosphorylation negatively influences its physiological function in microtubule assembly and stabilization (Lindwall \& Cole 1984). Moreover, aberrant phosphorylation is responsible for tau aggregation into NFT, which are the hallmark of AD (Grundke-Iqbal et al. 1986). Thus, tau protein is under the control of kinases and phosphatases that together maintain its physiological phosphorylation. The most important kinases implicated in tau hyperphosphorylation are GSK-3 $\beta$ (Takashima 2006), cyclin-dependent kinase 5 (cdk5) (Jicha et al. 1999) and protein kinase A (PKA) (Lee \& Leugers 2012). Recently, activated AMPK, which is important for maintaining cellular energy levels, was characterized as a tau kinase and shown to phosphorylate tau at several epitopes (Domise et al. 2016).

Another important component maintaining proper neuronal function are neurofilaments (NF) that form the neuronal cytoskeleton (Yuan et al. 2017). Damaged cytoskeleton observed in different neurodegenerative disorders is connected to accumulation of pathologic structures, such as NFT. It was discovered that some types of neurons, such as pyramidal neurons from neocortex or pyramidal neurons of cornu ammonis 1 (CA1), contain specific NF triplets which seem to make neurons more susceptible to neurodegeneration (Vickers et al. 2016). Cytoskeleton damage is also connected to formation of A $\beta$ plaque-associated dystrophic neurites which contains increased amount of NF, such as NF triplets. It is not properly known if $A \beta$ plaques precede or are the consequence of the dystrophic neurites (Vickers et al. 2016).
Apart from senile plaques and NFT, AD is characterized by decreased synaptic plasticity (Sheng et al. 2012, Skaper et al. 2017), increased oxidative stress (Zhao \& Zhao 2013) and neuroinflammation (Heneka et al. 2015), decreased neurogenesis (Rodriguez \& Verkhratsky 2011) and dysregulated calcium homeostasis (Bezprozvanny 2010).

Decreased synaptic plasticity is observed in the brains of $\mathrm{AD}$ patients long before the appearance of $\mathrm{A} \beta$ plaques or NFT and correlates well with the memory deficit (Terry et al. 1991). According to the amyloid hypothesis of $\mathrm{AD}$, synapse failure is most likely caused by the presence of soluble toxic A $\beta$ oligomers. The strength of synapses is measured by long-term potentiation (LTP). Decreased LTP was observed in animal models carrying mutations in APP or PS1 and in animals that had been intracerebroventricularly (ICV) injected with $A \beta_{1-40}$ or $\mathrm{A} \beta_{1-42}$ (Rowan et al. 2003). However, this hypothesis also has its detractors. Decreased synaptic plasticity manifested by decreased LTP and memory decline was observed in rats with diet-induced insulin resistance (Stranahan et al. 2008). Decreased synaptic plasticity is manifested by reduced levels of presynaptic or postsynaptic density proteins. Synaptophysin, a presynaptic vesicle protein, is decreased in TG19959 mice carrying human APP with two mutations (Tampellini et al. 2010) and in APP/PS1 mice (McClean et al. 2011). Another presynaptic protein that is decreased in AD brains, mainly in the cortex, is GAP43 protein (de la Monte et al. 1995, Bogdanovic et al. 2000). The role of tau at synapses has been extensively studied (Pooler et al. 2014). Tau is found in presynaptic and postsynaptic components, where it forms part of the postsynaptic density (PSD) complex involving PSD95, a major scaffolding protein that is important for synaptic plasticity and transmission. Hyperphosphorylation of tau destabilizes this complex and results in impaired synaptic plasticity (Forner et al. 2017). Moreover, reduced expression of PSD95 has been found in mouse models of tauopathy as well as in a mouse model of amyloidopathy (Shao et al. 2011). Neurogranin, another postsynaptic protein, is a marker of early synaptic dysfunction, and decreased levels of neurogranin are observed in patients with AD (Casaletto et al. 2017).

To some extent, synaptic plasticity can be increased by neurogenesis, a physiological process that occurs especially in the dentate gyrus (DG) of the hippocampus. With aging, neurogenesis decreases; however, neurogenesis is much more impaired in $\mathrm{AD}$ brains $(\mathrm{Mu} \&$ Gage 2011, Rodriguez \& Verkhratsky 2011). The method most frequently used to measure neurogenesis is the labeling 
of newborn neurons with bromodeoxyuridine (BrdU), which is a marker of DNA synthesis. In this method, proper interpretation of data and the use of appropriate control samples are required to discriminate neurogenesis from DNA synthesis, e.g. in microglia or other cell types (Taupin 2007). Newborn neurons can be detected by immunohistochemical staining for doublecortin (DCX) whose level is decreased in the hippocampi of AD patients. The decline could also be connected to decreased levels of brain-derived neurotrophic factor (BDNF), a member of the neurotrophin family that is important in memory formation, neuronal development and neurogenesis, in AD brains (Numakawa et al. 2017). For instance, BDNFinfused to DG of adult rats for 2 weeks significantly ameliorated neurogenesis compared to vehicle-treated group (Scharfman et al. 2005). BDNF activates the TrkB receptor (tropomyosin receptor kinase B), which can further increase activation of Akt, ERK and cAMP response element-binding protein (CREB), kinases that have been implicated to play a role in memory formation (Numakawa et al. 2017).

Neuroinflammation was shown to be connected to AD pathology (Hauss-Wegrzyniak et al. 1998). Neuroinflammation is mediated through increased activation of microglia and astrocytes, both of which are found to co-localize with $\mathrm{A} \beta$ plaques (Heneka et al. 2015). Activated microglia can be immunohistocemically detected by staining with ionized calcium-binding adapter molecule 1 (Iba-1), which is also known as allograft inflammatory factor 1 (AIF-1) (Heneka et al. 2015). Astrocytes are important in proper brain development and in the maintenance of brain energy homeostasis as well as for synaptic plasticity and LTP (Hol \& Pekny 2015). In general, astrocytes can be stained using antibodies against glial fibrillary acidic protein (GFAP), the expression of which increases with age (Teter 2009). However, only reactive astrocytes that show changes in cellular morphology and increased levels of GFAP increase neuroinflammation and lead to AD progression ( $\mathrm{Hol} \&$ Pekny 2015, Osborn et al. 2016).

MRI and PET are established imaging techniques for diagnosis of AD (Scheltens et al. 2016) as is multimodal chemical imaging using matrix-assisted laser desorption/ ionization mass spectrometry (MALDI-MS). This analytic approach shows great potential for comprehensive, highresolution molecular analysis of histological features at cellular length scales with high chemical specificity (Kaya et al. 2017). Moreover, cerebrospinal fluid biomarkers in diagnosis of early Alzheimer's disease might be very useful (Blennow et al. 2015). It was demonstrated that amyloid PET and CSF biomarkers identify early-stage AD equally accurately (Palmqvist $e t$ al. 2015).

\section{Leptin as a key player in food intake regulation: a role in neurodegeneration}

Leptin plays a key role not only in neurons that regulate energy homeostasis but also in neurons that are associated with learning and memory. Leptin, a satiety hormone that is produced in adipose tissue, is increased in the fed state and decreased during food restriction and fasting (Spiegelman \& Flier 2001). The anorexigenic effect of leptin is mediated in the Arc of the hypothalamus, where the leptin receptor $\mathrm{ObRb}$ is highly expressed. Numerous leptin receptors have also been detected at hippocampal synapses (Shanley et al. 2002). Interestingly, hippocampal ObRb mRNA expression was also found to be enhanced by food restriction (Lin \& Huang 1997), and the ObRb at hippocampal synapses was shown to be linked to hippocampal excitatory synaptic transmission (Shanley et al. 2001).

Leptin-deficient $o b / o b$ mice and $d b / d b$ mice with non-functional leptin receptors displayed significantly decreased wet brains weight and decreased expression of synaptic and glial proteins, similar to immature brain (Ahima et al. 1999). It seems that functional leptin is necessary for a proper brain development.

In Zucker $f a / f a$ rats and $d b / d b$ mice, both of which have non-functional ObRb, LTP and LTD were not found during electrophysiological tests of hippocampal slices, and spatial memory in the MWM was decreased (Li et al. 2002). For activity-dependent synaptic plasticity in the brain, activation of N-methyl-D-aspartate glutamate receptors (NMDAR) is the most important. After NMDARmediated calcium influx to the cytoplasm, another glutamate receptor, $\alpha$-amino-3-hydroxy-5-methyl-4isoxazolepropionic acid (AMPAR), is transported from the Golgi apparatus to the cell membrane (Moult et al. 2010). The transport of AMPAR exemplifies the principle of activity-dependent synaptic plasticity; LTP is mediated by AMPAR insertion into the membrane, whereas removal of AMPAR from the membrane mediates LDP (Collingridge et al. 2004, McGregor \& Harvey 2017).

Leptin could contribute to AMPAR-mediated synaptic plasticity through Janus activated kinase 2 (JAK2), which phosphorylates ObRb (Harvey et al. 2006, Irving \& Harvey 2014, McGregor \& Harvey 2017). JAK2 directly activates/phosphorylates the signal transducer and activator of transcription 3 (STAT3). Phosphorylation of 
STAT3 enables it to cross the nuclear membrane and act as a transcription factor for genes encoding key prosurvival proteins in neurons (Dziennis \& Alkayed 2008). $\mathrm{ObRb} / \mathrm{JAK} 2$ transphosphorylation is negatively regulated by the suppressor of cytokine signaling 3 (SOCS3) and protein tyrosine phosphatase 1B (PTP1B). JAK/STAT signaling has been linked to NMDAR-dependent synaptic plasticity; it was shown in hippocampal slices that JAK2 activation contributes to NMDAR-induced LTD. The effect of leptin on synaptic plasticity (Harvey et al. 2006) and leptin-induced synaptic plasticity (Moult \& Harvey 2011) have been investigated and established.

In addition to JAK2, ObRb/JAK2 transphosphorylation activates/phosphorylates two other signaling pathways/ kinases, PI3K and MAPK. Because PI3K and MAPK inhibitors block the potentiating effect of leptin on NMDA-induced increases in intracellular $\mathrm{Ca}^{2+}$, leptin involvement in NMDA activation also seems possible (Shanley et al. 2001). All three leptin signaling pathways were suggested to affect synaptic plasticity in particular areas of the hippocampus (McGregor \& Harvey 2017). Moreover, leptin was shown to affect the proliferation of DG hippocampal neurons through STAT3 and Akt activation (Garza et al. 2008).

Distorted neuronal leptin signaling is observed not only after improper brain development but also in old age and in neurodegenerative disorders such as $\mathrm{AD}$. In the hypothalami of old rats, increased PTP1B (Morrison et al. 2007) and enhanced SOCS3 expression (Peralta et al. 2002) have been linked to leptin resistance. Therefore, one could expect that old age-induced leptin resistance also occurs in the hippocampus, as adult hippocampal neurogenesis in mice was shown to be mediated through STAT3 and Akt (Garza et al. 2008). In transgenic APP/PS1 mice, hippocampal ObR mRNA levels were decreased, indicating that $A \beta$ toxicity could negatively affect leptin signaling (Pedros et al. 2015). This was confirmed in Tg2576 mice that carry only the APP Swedish mutation; in these animals, lower STAT3 phosphorylation was detected and was reversed by $\mathrm{A} \beta$ passive immunization (Chiba et al. 2009). Moreover, in crosses of APP23 mice bearing the APP Swedish mutation with ob/ob mice, the animals' cognitive functions in the MWM were attenuated in comparison to those of mice of either of the parental genotypes. Interestingly, the progeny of this cross displayed exacerbated glucose intolerance, but $A \beta$ was not affected (Takeda et al. 2010).

Distorted leptin signaling also affects neuronal tau protein phosphorylation. In $d b / d b$ mice overexpressing human mutant tau protein (so-called Tau P301L mice), exacerbated hippocampal tau phosphorylation and NFT were detected (Platt et al. 2016). Activation of GSK-3 $\beta$, the major tau protein kinase, was suspected to play a leading role in these changes.

A question arose regarding whether leptin can reverse already established changes resulting from old age or neurodegenerative disease. Leptin reversed the negative effect of $A \beta$ on LTP- and A $\beta$-induced LTD in hippocampal slices and increased the survival of A $\beta$-treated cortical neurons through ERK and Akt activation (Doherty et al. 2013). Treatment of CRND8 mice with the Swedish and Indiana (V717F) mutation with leptin for 2 months attenuated $A \beta$ load in the blood and the brain, decreased tau protein phosphorylation and improved performance in object recognition and contextual fear tests (Greco et al. 2010). Leptin prevented spatial memory attenuation in both the Y-maze and MWM tests in healthy rats that received repeated ICV administration of $A \beta$ and reversed the $\mathrm{A} \beta$-induced decrease in late phase-LTP recorded as hippocampal field potentials (Tong et al. 2015). Treatment of APP/PS1 mice for 2 weeks with intranasally administered leptin combined with the peroxisome proliferatoractivated receptor $\gamma(\operatorname{PPAR} \gamma)$ agonist pioglitazone attenuated memory deficits recorded in the Y-maze and decreased brain $\mathrm{A} \beta$ levels (Fernandez-Martos et al. 2017). Acute intrahippocampal administration of leptin positively affected foot shock avoidance and step down inhibition avoidance in the T-maze in 12-month-old SAMP8 mice (Farr et al. 2006).

In conclusion, leptin is a potential cognitive enhancer; it improves hippocampus-dependent learning and memory and is probably involved in AMPAR trafficking, neuronal morphology and activity-induced synaptic plasticity. This ability declines with age (Scarpace et al. 2000), resulting in neurodegenerative changes such as AD.

\section{Ghrelin, physiological antagonist of leptin with potential neuroprotective function}

Ghrelin, the only known orexigenic gut hormone and endogenous ligand of GHS-R1a, is secreted primarily from the stomach. This 28 -amino-acid peptide contains a serine esterified by n-octanoic acid, a unique modification necessary for its biological activity (Kojima et al. 1999). Ghrelin maintains the positive energy balance of the organism and has a key role in increasing appetite, food intake and body weight, facilitating adipose tissue accumulation and regulating energy metabolism (Delporte 2013). These effects, together with the anti-inflammatory 
effects mediated by peripherally distributed GHS-R1a, make ghrelin administration a promising anti-cachectic therapeutic strategy (Holubova et al. 2018).

Peripherally released and centrally acting leptin and ghrelin are both regulators of appetite/feeding and are physiological antagonists as shown for example on their opposite role in regulation of release of orexigenic (e.g. neuropeptide Y) or anorexigenic (e.g. melanocortins) peptides in nucleus arcuatus (Fig. 1). On the other hand, they play a positive role in neuroprotection and brain function (de Candia \& Matarese 2018). Ghrelin has been shown to be involved in numerous higher brain functions such as memory, reward and mood, which are disrupted in neurodegenerative disorders, including AD (Procaccini et al. 2016, Shi et al. 2017a). Ghrelinknockout mice showed decrease number of spine synapse and impaired memory tests compared to wild-type mice (Diano et al. 2006).

Neuroprotective effects of ghrelin have been shown in several models of AD-like pathology such as SAMP8 mice (Diano et al. 2006), 5xFAD mice with $\mathrm{A} \beta$ pathology (Jeong et al. 2018), mice (Santos et al. 2017) or rats (Eslami et al. 2018) with ICV injected $A \beta_{1-40}$. In these studies, repeated administration of ghrelin or its agonists caused improved performance in memory tests and decreased markers of $\mathrm{A} \beta$ pathology.

Finally, orexigenic neuropeptides positively influenced by central action of ghrelin, such as neuropeptide Y, galanin or orexin were found to act also in hippocampus and are involved in learning and memory as well (Beck \& Pourie 2013).

This is just very brief description of a role of orexigenic peptides in neuroprotection and further details are beyond the scope of this review, dedicated namely to anorexigenic peptides.

\section{The effect of anorexigenic peptides in AD-like pathology}

The brain-gut axis affects neural function and controls eating behavior through biochemical signaling between the endocrine and nervous systems. This signaling is mediated by peptide hormones that are released both in the gastrointestinal tract and in the CNS (Wilson \& Enriori 2015, Zanchi et al. 2017). Anorexigenic hormones involved in short-term regulation include the gut hormones GLP-1, peptide tyrosine tyrosine (PYY), cholecystokinin (CCK), amylin, oxyntomodulin that are controlled by the long-term satiety signal leptin (Frago \& Chowen 2015,
Prinz \& Stengel 2017). These gut hormones are released into the digestive system and then act centrally as satiety signals that decrease food intake; their action occurs specifically in the hypothalamus and brainstem, which act as control centers for hunger and satiety. The Arc of the hypothalamus is considered the most important nucleus in the control of feeding behavior. Neurons in the hypothalamus receive information from the periphery; then, first-order neurons in the Arc and second-order neurons in the paraventricular nucleus (PVN) and the ventromedial nucleus (VMN) are activated, causing them to release neuropeptides that regulate food intake (Schwartz et al. 2000).

These neuropeptides include proopiomelanocortin (POMC), cocaine- and amphetamine-regulated transcript (CART) peptide in the Arc and prolactin-releasing peptide (PrRP) and corticotropin-releasing peptide (CRH) in the PVN, all of which are positively influenced by leptin (Sohn 2015, Mandal et al. 2018), as shown in Fig. 1.

In addition to their role in the regulation of food intake, the above-mentioned peptide hormones, which are released both peripherally and centrally and act centrally, were recently proposed to function not only in the control of energy metabolism but also as growth factors that stimulate cell growth and cell repair in neurons (Holscher 2018). These hormones were also proposed to restore insulin signaling pathways in brain areas associated with learning and memory formation, such as the hippocampus, and thus to positively influence spatial and episodic memory (Mandal et al. 2018), as shown in several preclinical studies. Like insulin and leptin, they can also modulate the insulin/leptin signaling pathway, thereby acting as neuroprotective hormones (Yarchoan \& Arnold 2014), improving hippocampal synaptic plasticity and enhancing cognitive performance (Fadel et al. 2013).

Table 1 describes the effects of pharmacological interventions involving anorexigenic peptides (leptin, melanocortins, CART peptide, PrRP, amylin and GLP-1 and glucose-dependent insulinotropic polypeptide (GIP) analogs) on spatial memory and on the parameters of neurodegeneration in cortex and/or hippocampi in rodent models of AD-like pathology.

\section{Melanocortins in experimental models of AD-like pathology}

The role of melanocortins and their receptors MC3 and MC4 in the CNS, especially in the hypothalamus, has been extensively investigated. Melanocortins are neuropeptides that are released in the Arc and act at specific receptors 

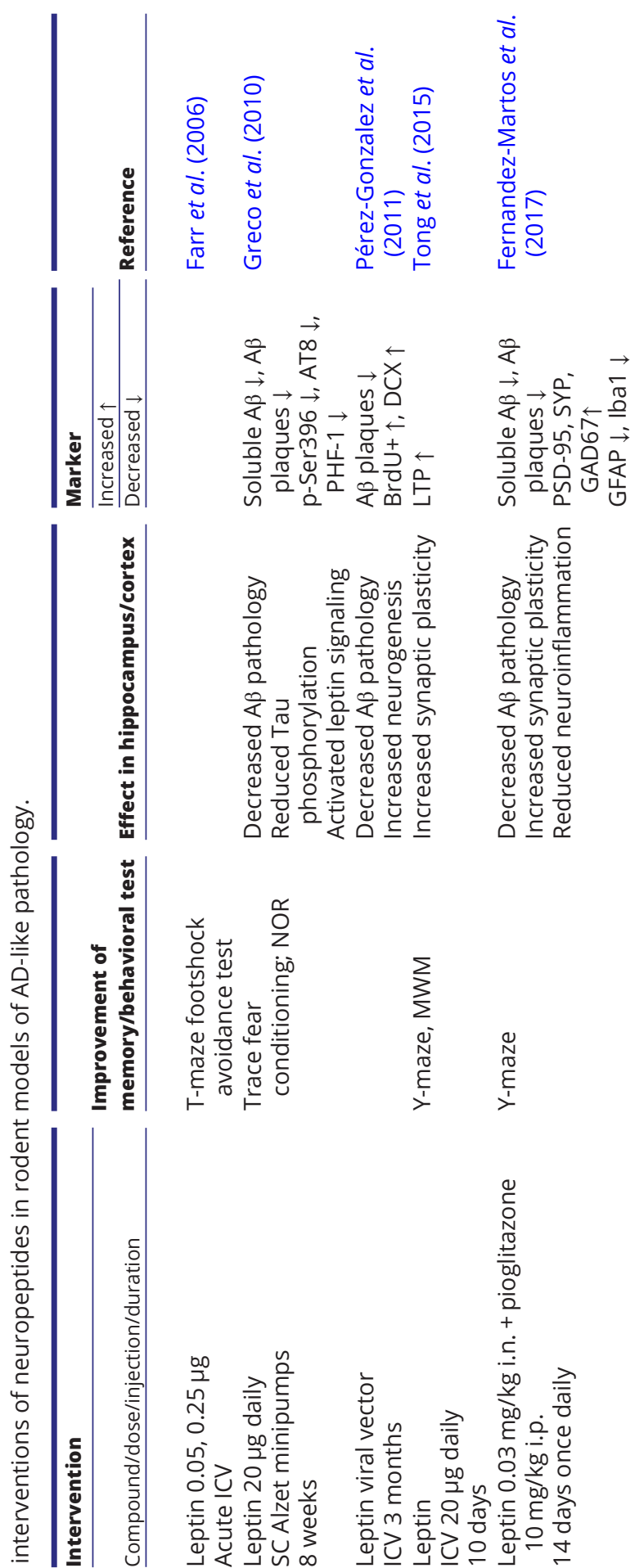

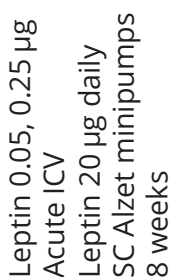

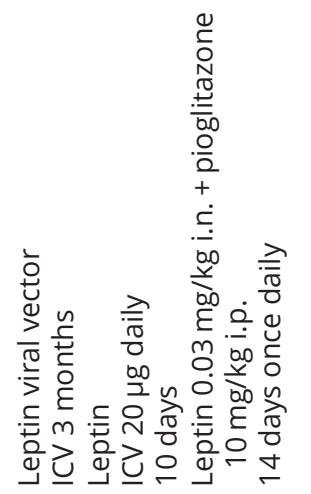

$\sum_{\sum}^{\sum}$
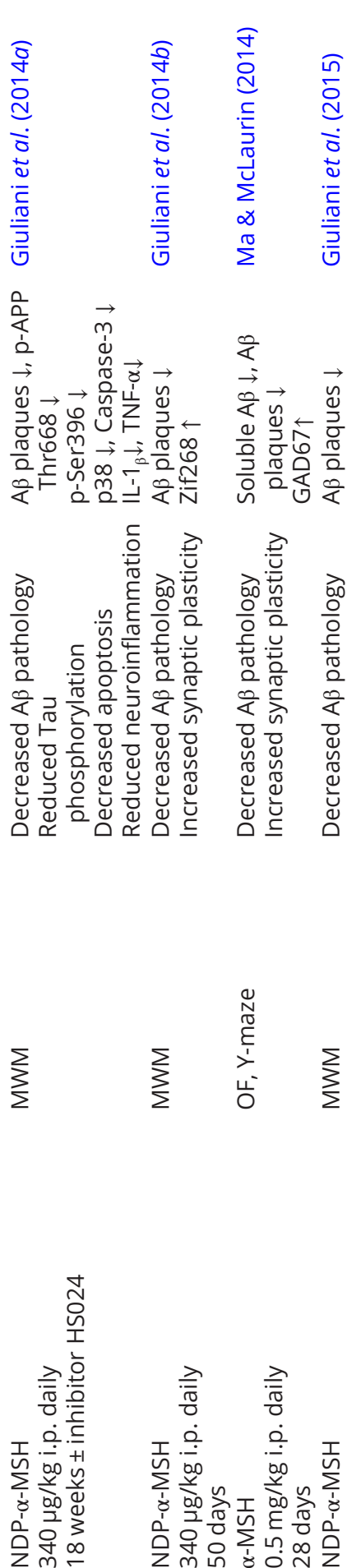

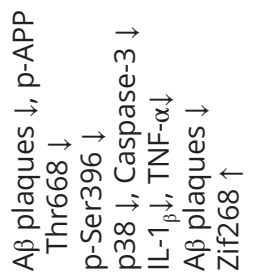
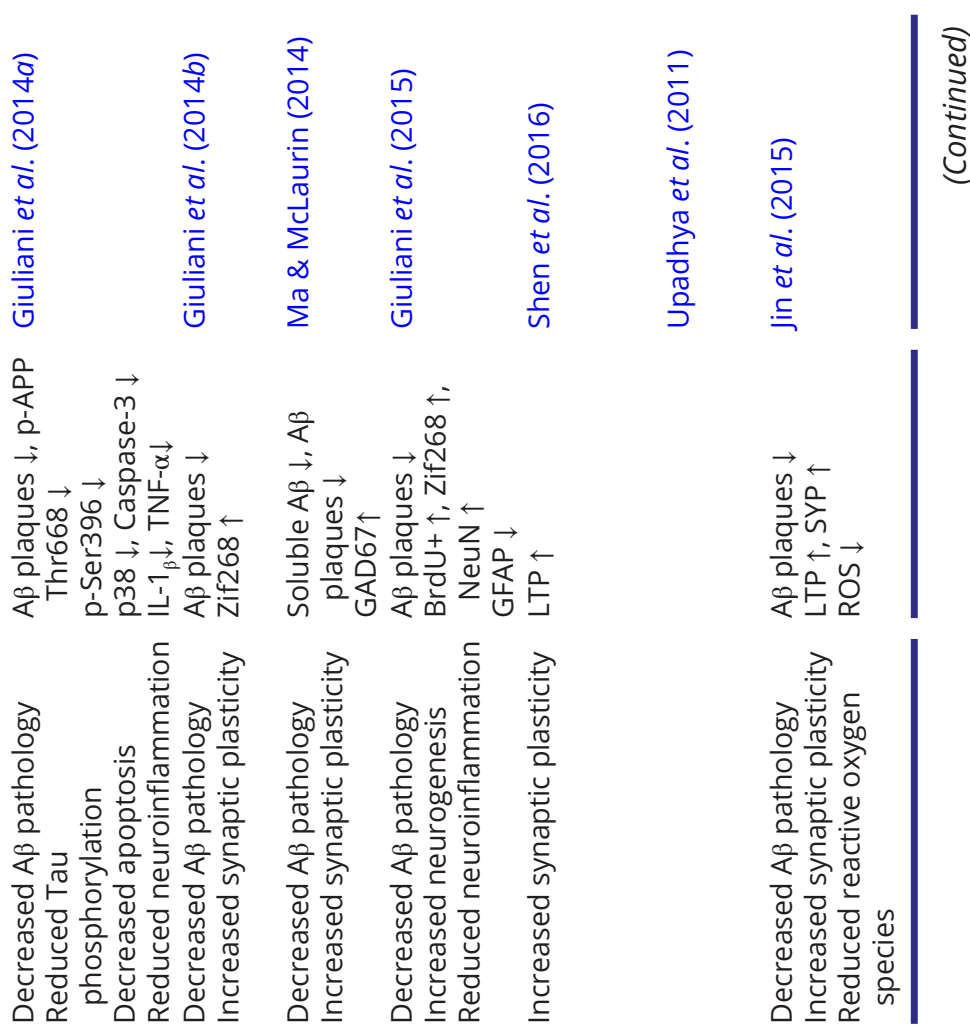

$\sum_{\sum}^{\sum}$
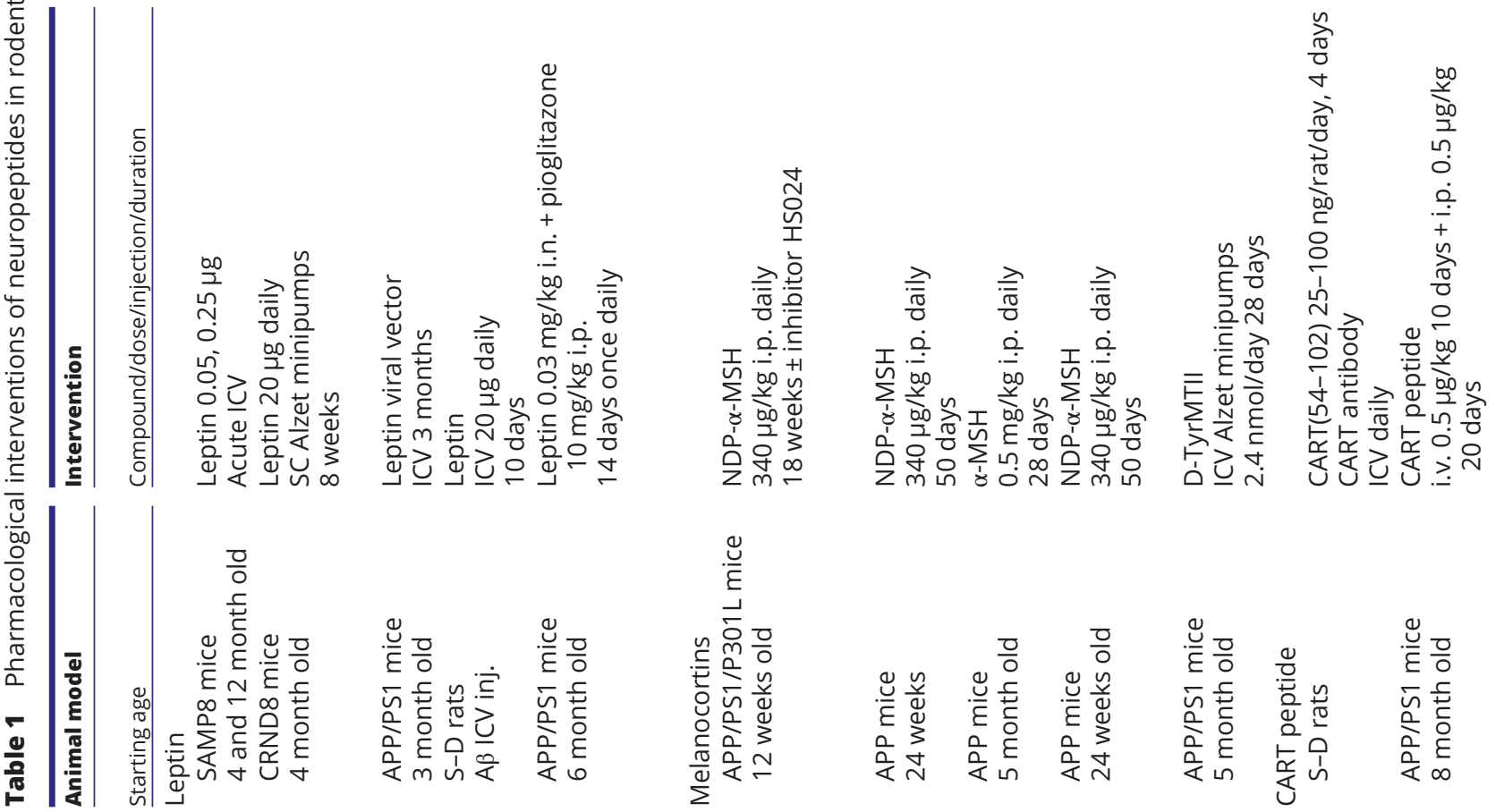


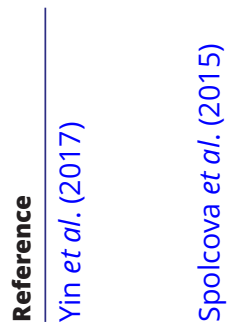

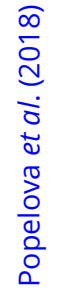

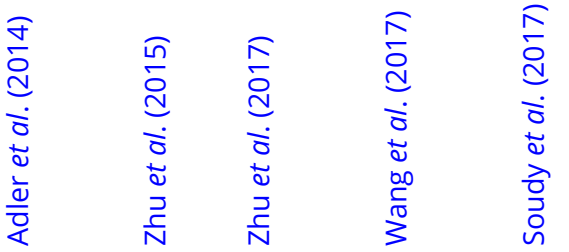
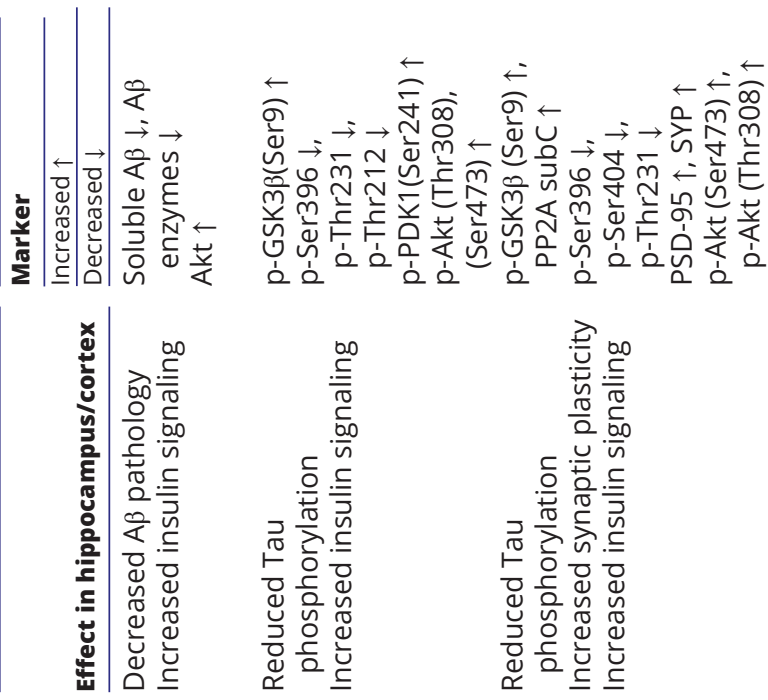

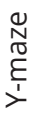
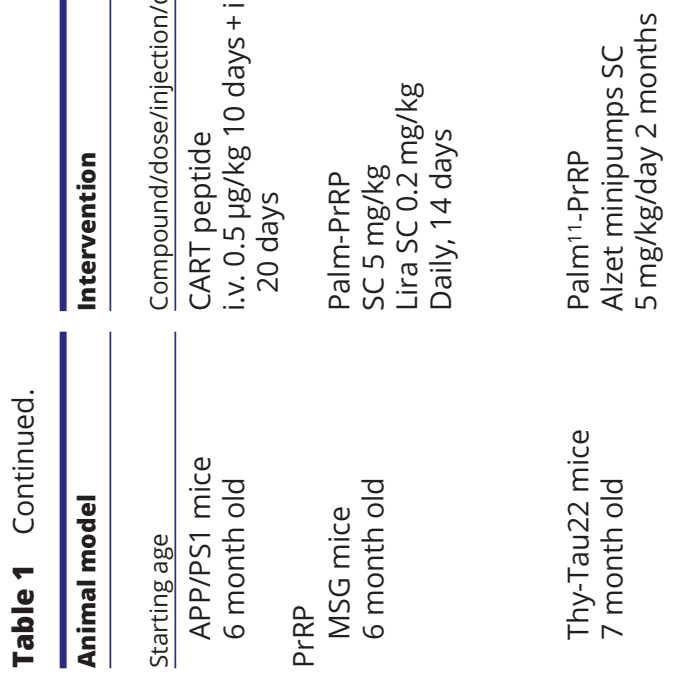
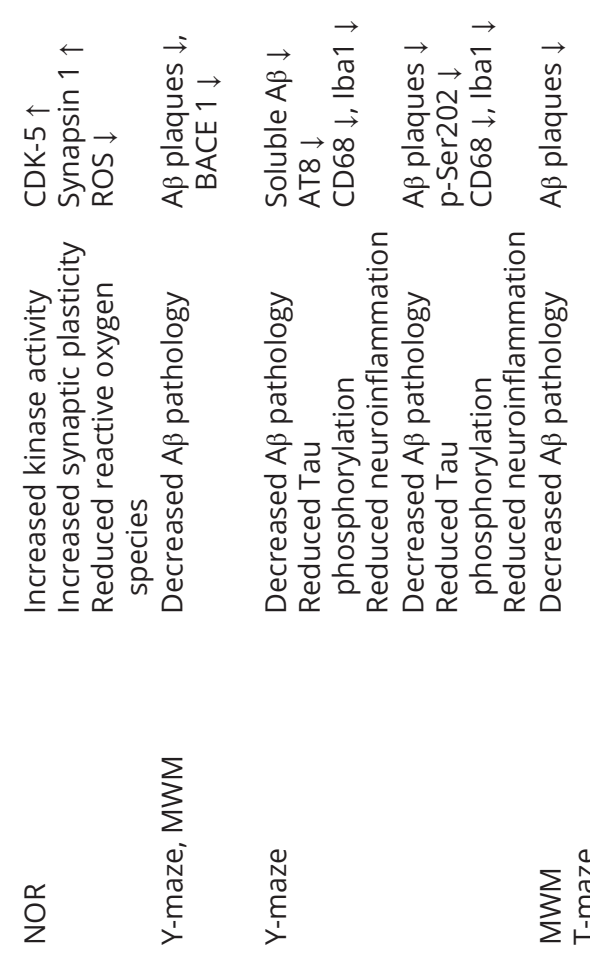

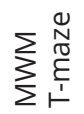

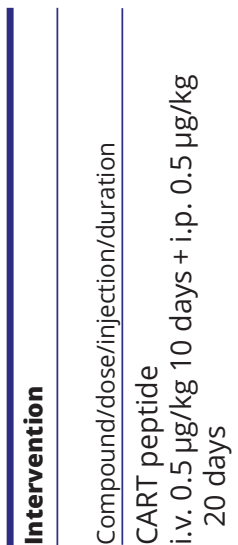

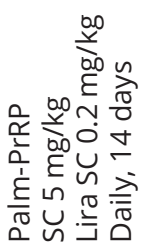

$0<$ in
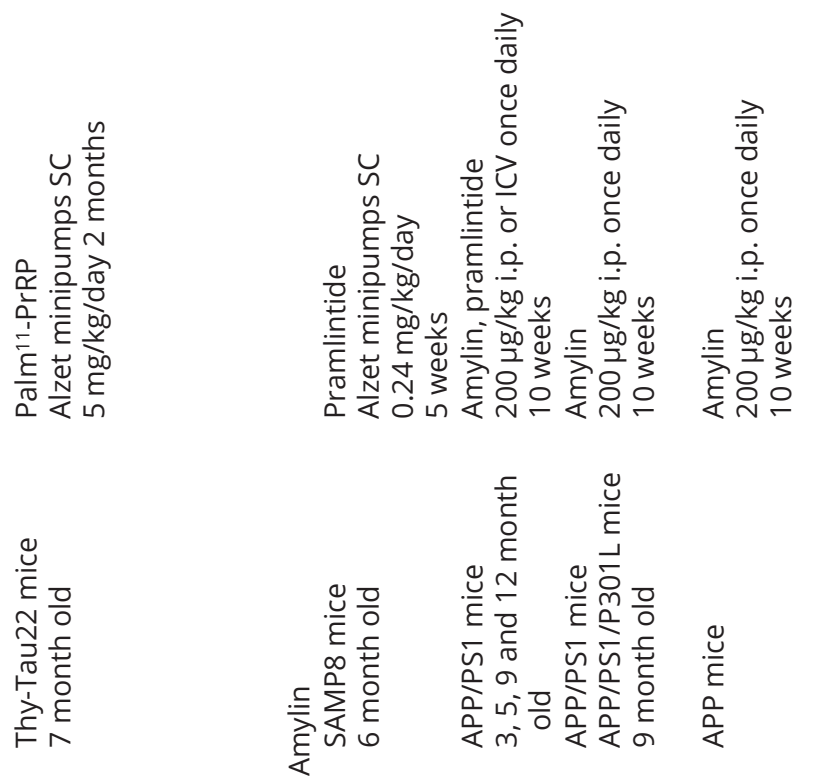

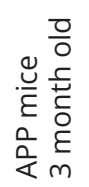

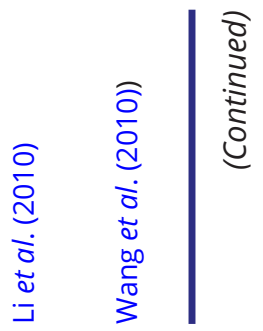

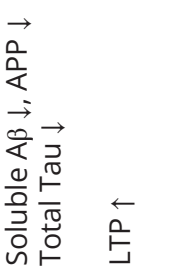

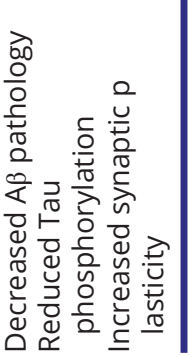

$\sum_{\Sigma}$
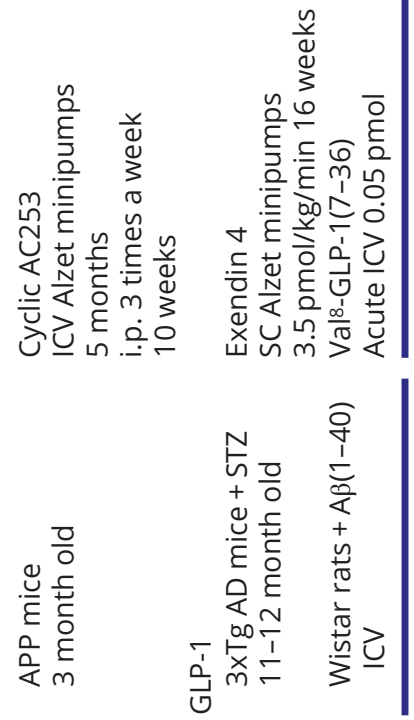


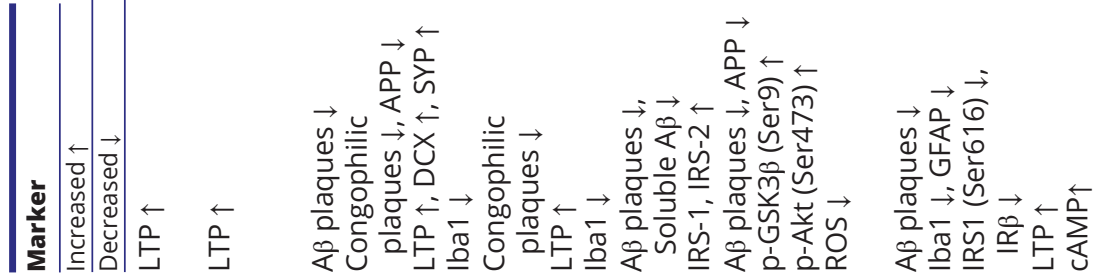

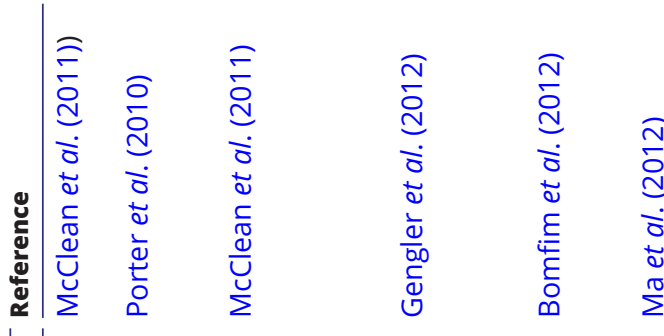

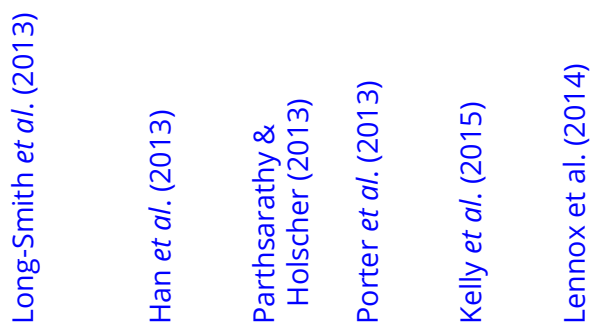

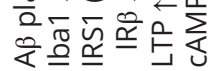
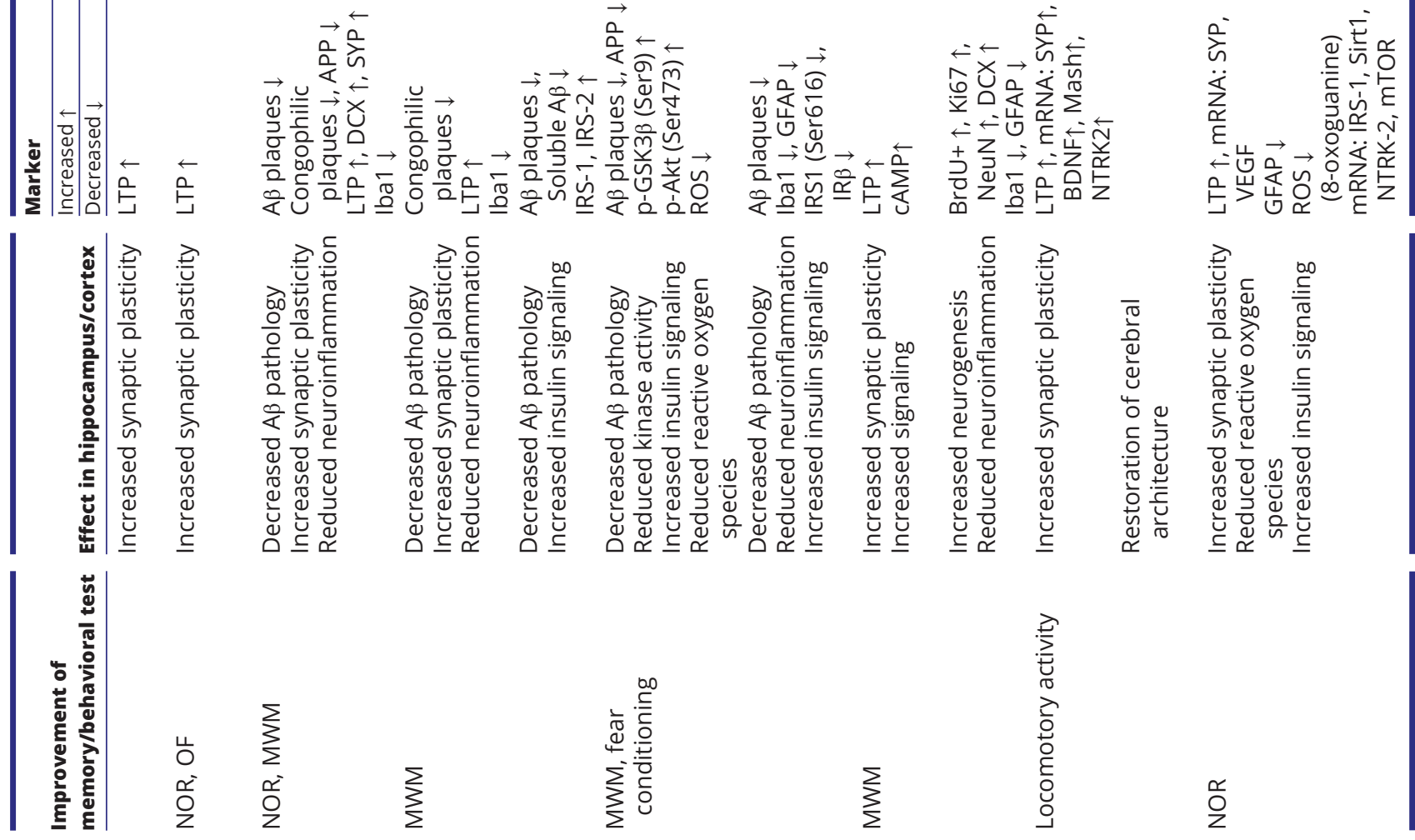

$\sum_{\Sigma}^{\sum}$
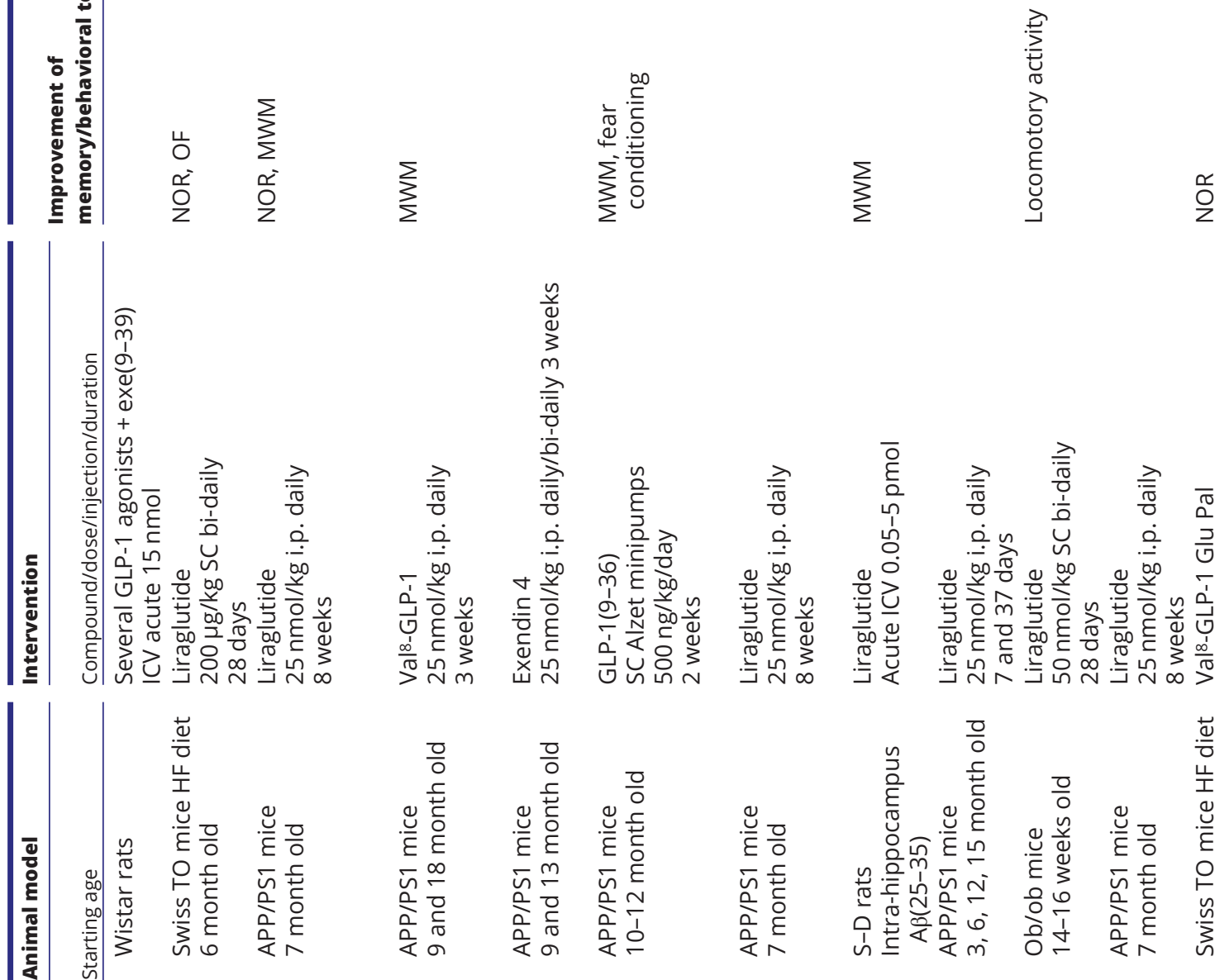

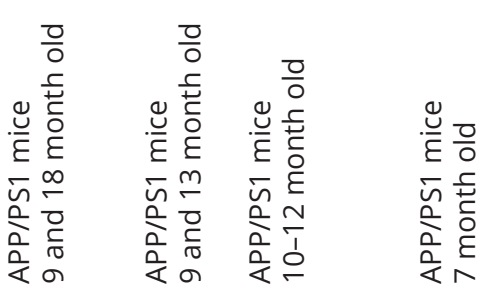

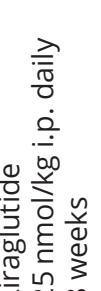

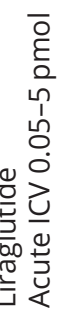

ֻ
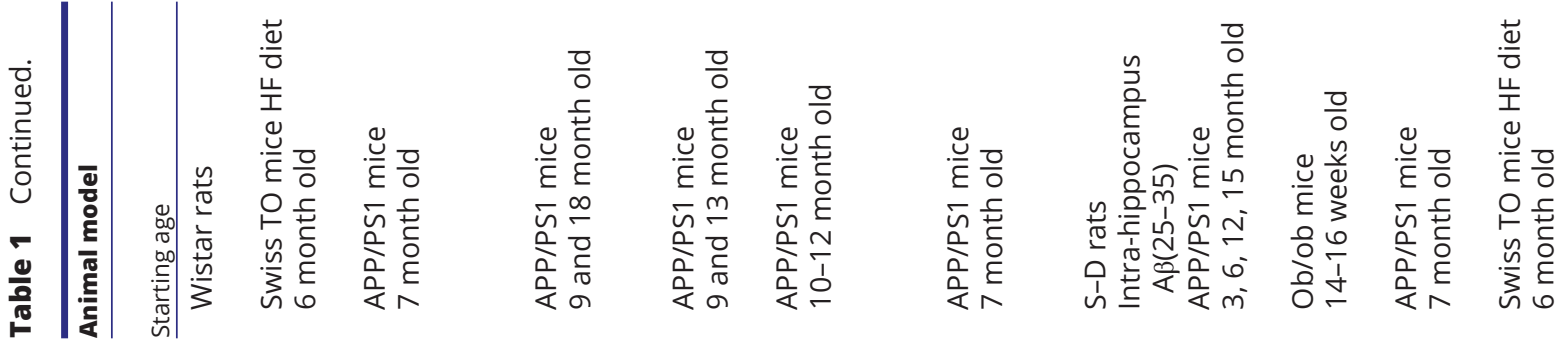

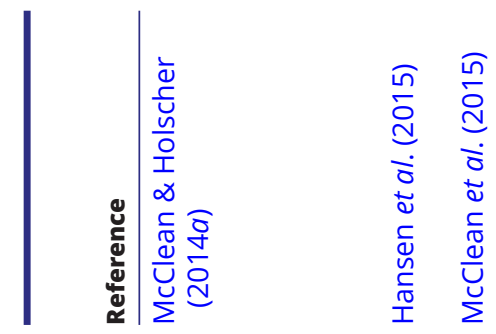

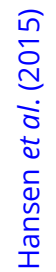
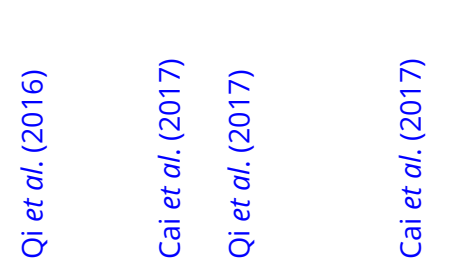

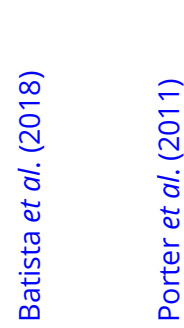

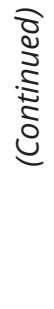

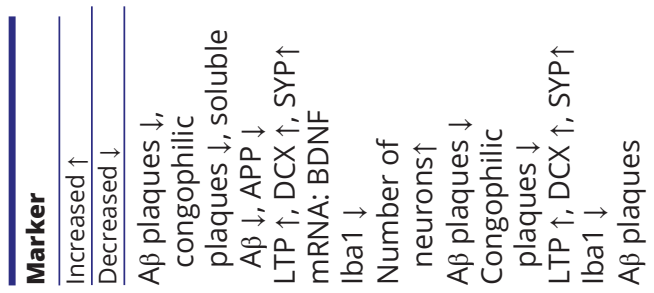
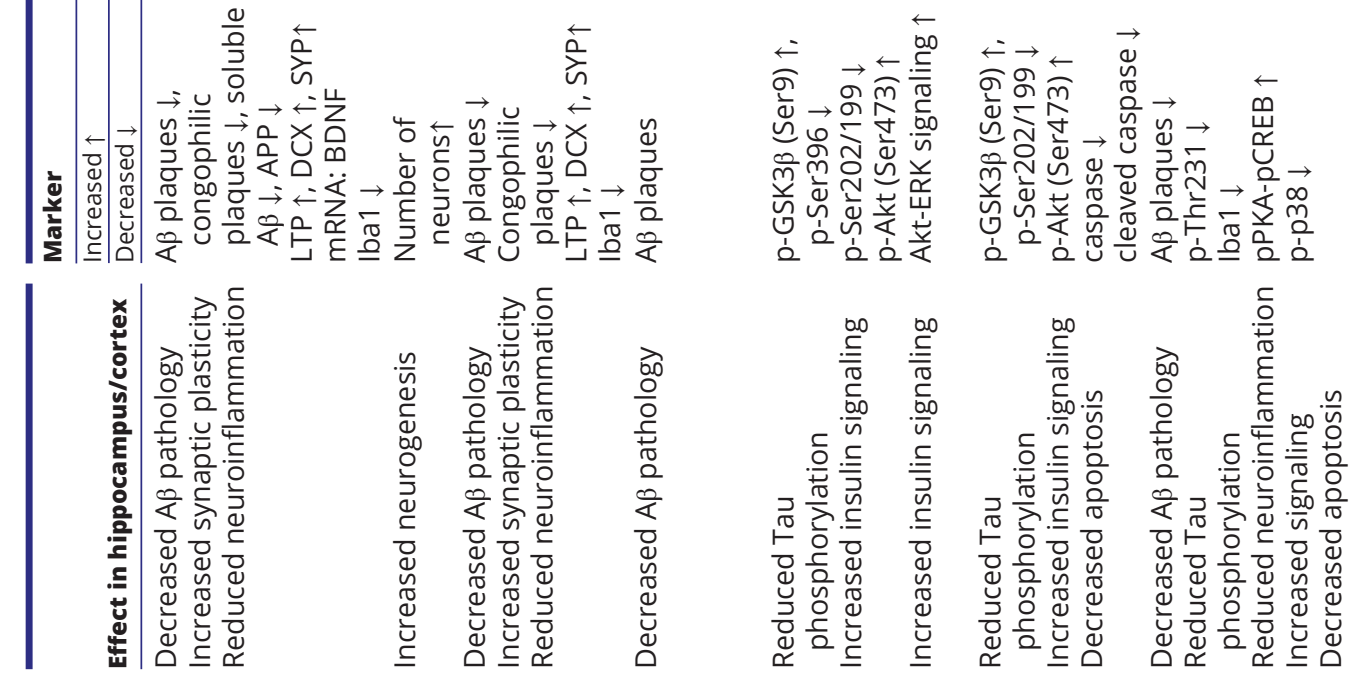

$\stackrel{\leftarrow}{\Xi}$
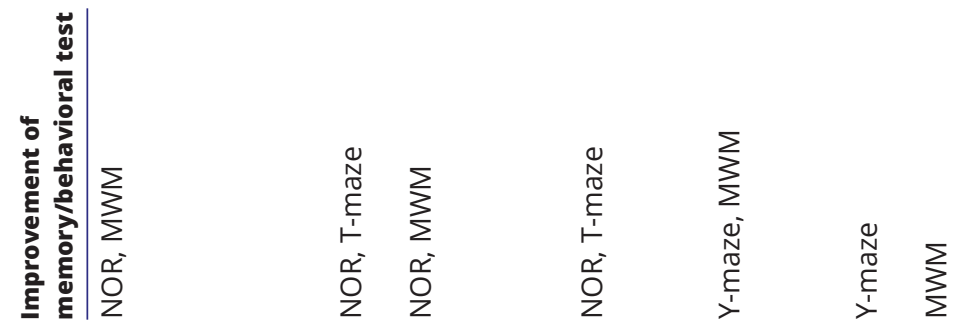

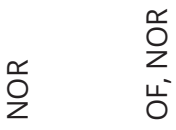
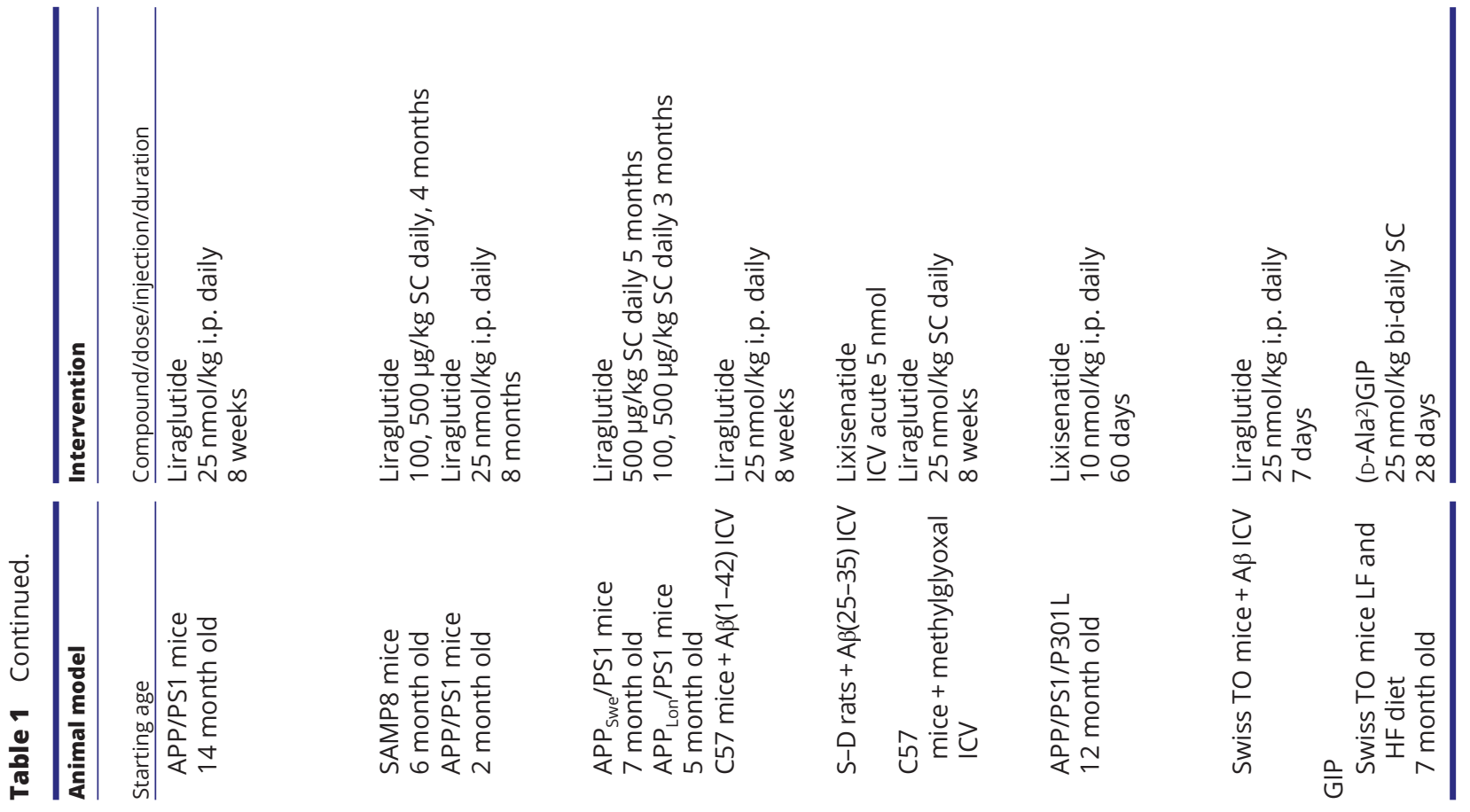

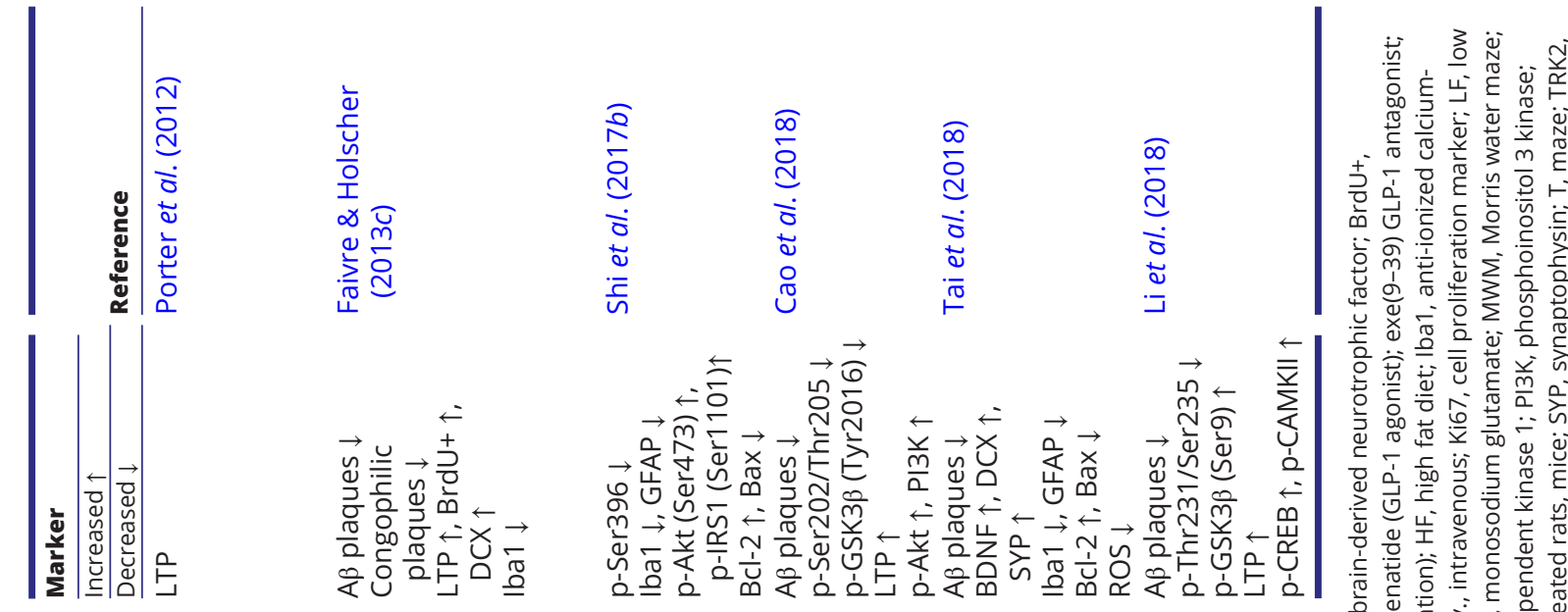

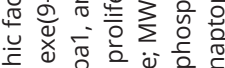
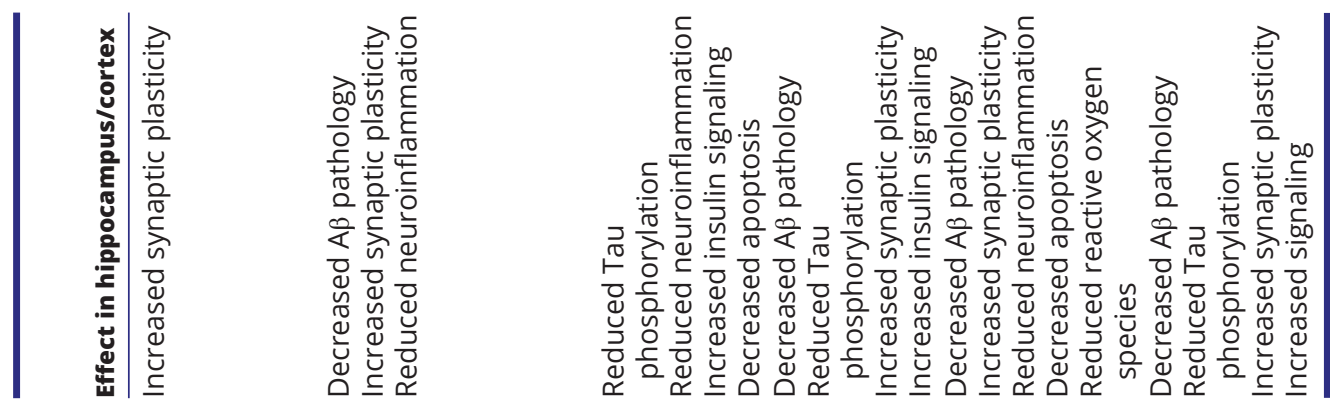

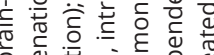

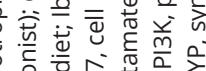

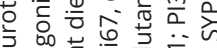

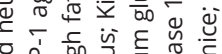

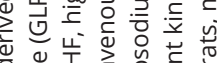

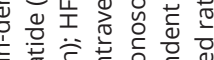

$\underline{\underline{x}} \geq \vec{z} \overline{0}$
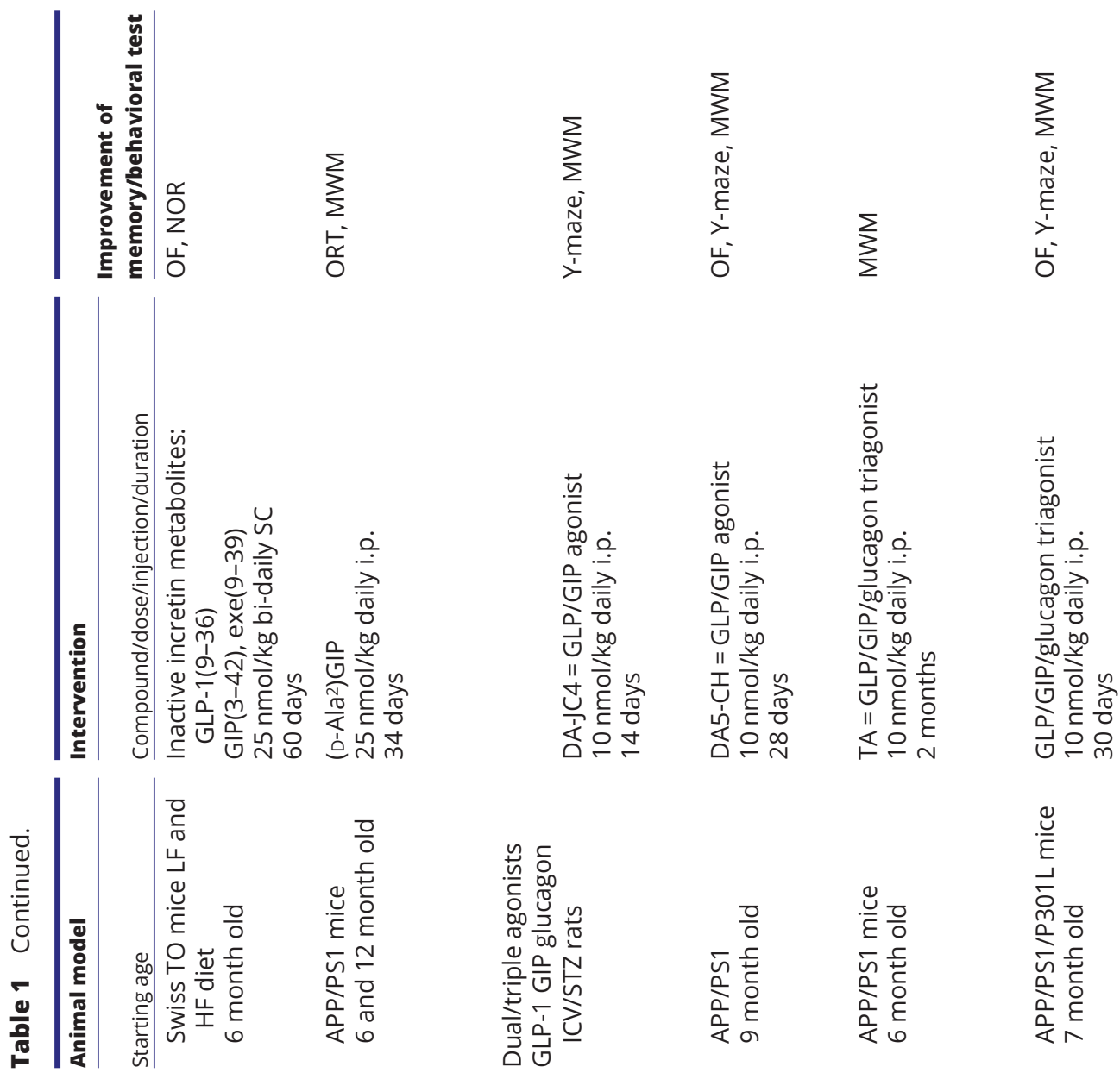

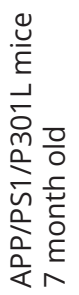

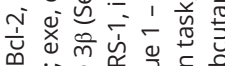

들

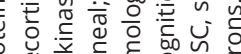

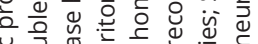

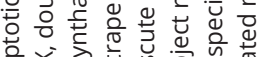

응

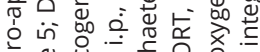

은

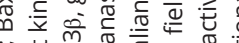

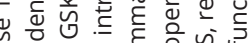

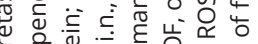

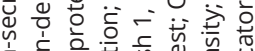

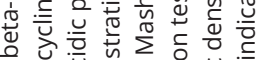

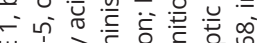

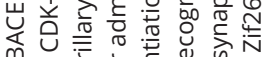

至

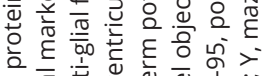

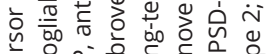

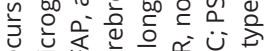

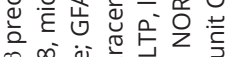

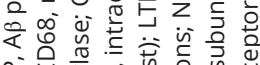

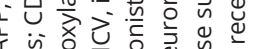

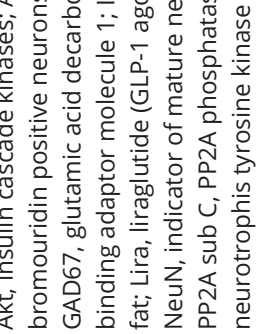


within the brain (Giuliani et al. 2017). The neuroprotective properties of melanocortin agonists have been demonstrated in several models of neurodegeneration (Giuliani et al. 2017). In different mouse models of AD-like pathology, such as in Tg2576 mice (Giuliani et al. 2014b, 2015), TgCRND8 mice (Ma \& McLaurin 2014) and in APP/PS1/P301L mice (Giuliani et al. 2014a), intraperitoneal (i.p.) injection of the melanocortin analog NDP- $\alpha-\mathrm{MSH}$ (Nle $\left.{ }^{4}, \mathrm{D}-\mathrm{Phe}^{7}\right)-\alpha$ melanocyte-stimulating hormone) or $\alpha$-MSH for several weeks improved synaptic plasticity and decreased neuronal loss, $A \beta$ levels, tau phosphorylation in brain. Behavioral tests of these animals showed improved cognitive function (Table 1). Increased neurogenesis and decreased neuroinflammation were also described (Giuliani et al. 2015).

\section{CART peptide in experimental models of AD-like pathology}

CART peptides are widely distributed in the CNS and are involved in the regulation of food intake, reward and endocrine functions, and stress responses (reviewed in Rogge et al. 2008, Lau \& Herzog 2014). Despite the large efforts that have been made in this area, CART peptide receptor(s) have not been identified to date, but specific binding and signaling in pheochromocytoma PC12 cells was described suggesting possible receptor in this cell line is present (Maletinska et al. 2007, Nagelová et al. 2014). Several studies report neuroprotective properties of natural CART peptide. In in Sprague-Dawley rats, ICV administration of CART peptide improved performance in Morris water maze (Upadhya et al. 2011). In APP/PS1 mice after repeated peripheral administration (Jin et al. 2015 , Yin et al. 2017) (Table 1), the number of $A \beta$ plaques was decreased, and memory performance as well as synaptic plasticity improved in these studies. However, it was proven that the CART peptide does not have a central effect on food intake lowering after peripheral administration (Jensen et al. 1999); thus, neuroprotective effect of CART peptide after i.v. or i.p. administration is very surprising since central effect is needed for CART peptide effect.

\section{PrRP in experimental models of AD-like pathology}

PrRP is an anorexigenic neuropeptide belonging to the family of so-called RF amide peptides with a C-terminal arginine and phenylalanine amide sequence; both of these amino acid residues are essential for proper biological activity (Boyle et al. 2005, Maletinska et al. 2011).
The first described effect of PrRP, release of prolactin from the pituitary tumor cell line RC-4B/C (Hinuma et al. 1998), gave the name to the peptide. A direct prolactin-releasing effect of PrRP in mammals has, however, been questioned because no PrRP immunoreactive fibers were observed in the median eminence where classical hypophysiotropic hormones are released (Maruyama et al. 1999). This, together with the discovery that prolactin positive cells in the human pituitary do not co-localize with the PrRP receptor (Abe et al. 2003) and the finding that PrRP increases prolactin responses to TRH (Spuch et al. 2007), but itself does not significantly increase prolactin secretion in primary rat pituitary cells (Samson et al. 1998), has suggested that prolactin release is probably not a primary function of PrRP (Taylor \& Samson 2001).

The presence of PrRP in hypothalamic nuclei implicated in maintaining energy balance suggested that it plays a role in food intake and weight regulation (Lawrence et al. 2000). However, because natural PrRP does not cross the BBB, new lipidized analogs that enable PrRP to act centrally after peripheral administration were designed (Maletinska et al. 2015, Prazienkova et al. 2017).

Two palmitoylated analogs of PrRP, palm-PrRP (Spolcova et al. 2015) and palm ${ }^{11-P r R P}$ (Popelova et al. 2018), were tested in two mouse models of neurodegeneration, as shown in Table 1. Palm ${ }^{1}$-PrRP was injected subcutaneously (SC) for two weeks into MSG-obese mice, in which obesity is caused by injection of newborn mice with monosodium glutamate (MSG), causing specific lesions in Arc (Spolcova et al. 2015). MSG-obese mice are leptin- and insulin-resistant, but they are normoglycemic (Matysková et al. 2008). At the age of six months, increased activation of GSK-3 $\beta$ and hyperphosphorylation of tau at several epitopes was observed in the hippocampi of MSG mice. Treatment with palm ${ }^{1}$-PrRP ameliorated activation of the hippocampal insulin signaling cascade, decreased activation of GSK-3 $\beta$ manifested by increased phosphorylation at Ser9, and attenuated tau phosphorylation at epitopes Ser396, Thr231 and Thr212 (Spolcova et al. 2015).

The PrRP analog palm ${ }^{11}$-PrRP was administered to THY-Tau22 mice for two months using SC Alzet osmotic minipumps (Popelova et al. 2018). The THY-Tau22 mice are a model of AD-like tau pathology in which mutated human tau protein is overexpressed. The mice exhibited increased tau hyperphosphorylation and spatial memory impairment (Schindowski et al. 2006). Spatial memory in the Y-maze test was improved in mice treated with palm ${ }^{11}$-PrRP compared to mice treated with vehicle. In hippocampi, attenuated tau phosphorylation was 
observed at Thr231, Ser396 and Ser404. Moreover, increased phosphorylation of Akt at Ser473 was observed. Akt activation is important for further activation of PSD95, causing it to be consequently increased (Popelova et al. 2018).

\section{Amylin in experimental models of AD-like pathology}

Amylin is a metabolic peptide hormone that is co-secreted with insulin from beta cells in the pancreas; it activates many of the downstream targets of insulin. In addition to improvement of glycemic control, it also influences gastric emptying and satiety after peripheral administration (Zhu et al. 2015). Pramlintide, a synthetic analog of amylin, activates many metabolic pathways in the CNS; it positively influences memory and enhances the insulin signaling pathway in the brain. These effects were demonstrated in several mouse models (Table 1), including the SAMP8 mouse model (Adler et al. 2014) and APP/PS1 mice (Zhu et al. 2015). After peripheral or central injections of amylin or pramlintide for several weeks, A $\beta$ and tau pathology in hippocampus was improved, and neuroinflammation decreased (Table 1; Soudy et al. 2017, Wang et al. 2017, Zhu et al. 2017).

\section{GLP-1 agonists, GIP agonists and dual and triple agonists in experimental models of AD-like pathology}

Incretins, namely, GLP-1 and GIP, represent one of the most studied groups of potentially neuroprotective compounds. Both are secreted by the small intestine when the glucose concentration is increased; they further stimulate the secretion of insulin, leading to lowering of blood glucose levels. In the periphery, incretin receptors are present in the pancreas; however, a large number of incretin receptors are found throughout the brain, mainly in the hippocampus (Vilsboll \& Holst 2004, Drucker 2006).

The problem with naturally occurring incretins is their low stability due to the cleavage of their N-terminal sequence by dipeptidyl peptidase IV (DPP IV). Therefore, incretin analogs with prolonged stability have been designed (Drucker 2006).

One of the most studied GLP-1 analogs, liraglutide, has been approved as a treatment for T2DM (Victoza, NovoNordisk) and obesity (Saxenda, NovoNordisk) and is now undergoing phase II clinical trial testing in $\mathrm{AD}$ patients (NIH 2010, Holscher 2018). Many studies of liraglutide have been performed in different $\mathrm{AD}$ animal models. In APP/PS1 mice, treatment with liraglutide for two months reduced the level of soluble $A \beta$ and $A \beta$ plaques, prevented reduction in the number of synapses, and improved spatial memory in the MWM in 7-monthold (McClean et al. 2011) or 14-month-old mice (McClean $\&$ Holscher 2014a) (Table 1). Chronic liraglutide treatment increased neurogenesis, as shown by increased levels of doublecortin and BrdU labeling in APP/PS1 mice of different ages (Parthsarathy \& Holscher 2013). Moreover, prophylactic administration of liraglutide to APP/PS1 mice for eight months prevented the formation of $A \beta$ plaques, decreased neuroinflammation, improved spatial memory in the MWM and increased neurogenesis (McClean et al. 2015) compared to vehicle-treated APP/PS1 mice. Using SAMP8 mice, enhanced spatial memory and an augmented number of neurons in the CA1 region of the hippocampus were observed after liraglutide treatment (Hansen et al. 2015). Liraglutide has also been tested in mouse models of obesity and/or diabetes. It improved metabolic parameters, including body weight and glucose levels, and increased LTP in DIO mice (Porter et al. 2010) and in $o b / o b$ mice (Porter et al. 2013). Liraglutide efficiently attenuates tau hyperphosphorylation. In DIO rats that developed T2DM, attenuation of the insulin signaling cascade and hyperphosphorylation of tau protein at different epitopes were observed; treatment of the animals with liraglutide for four weeks led to enhanced activation of kinases implicated in the insulin signaling cascade including increased phosphorylation of inhibitory Ser9 of GSK-3 $\beta$ and ultimately decreased phosphorylation of tau protein at Ser199, 202 and 396 (Yang et al. 2013). A similar mechanism of action of liraglutide was demonstrated in a model of tau pathology induced by administration of $\mathrm{A} \beta_{1-42}$ (Qi et al. 2016) or methylglyoxal (Qi et al. 2017); liraglutide treatment resulted in improved spatial memory as measured in the Y-maze and MWM tests, increased activation of Akt, decreased kinase activity of GSK-3 $\beta$, and subsequent attenuation of tau hyperphosphorylation. The results of these studies are summarized in Table 1.

Another potent analog of GLP-1 is exenatide, a synthetic analog of exendin-4; it was tested as a treatment for $\mathrm{AD}$ in a pilot clinical trial. Its effect is mediated through activation of the PI3/Akt pathway (Wang et al. 2015). Its neuroprotective properties were manifested in APP/PS1 mice; in these animals, exenatide reduced the phosphorylation of IRS- 1 at serine epitopes, a sign of insulin signaling impairment that resulted from A $\beta$-induced activation of JNK. Moreover, the treatment reduced the number of $A \beta$ plaques and the level of soluble $A \beta$, and improved memory in the MWM (Bomfim et al. 2012). In $3 x T g$ AD mice in which AD pathology was enhanced by 
injection of STZ to provoke diabetic conditions, treatment with exenatide resulted in reduced numbers of $A \beta$ plaques (Li et al. 2010). In STZ rats, exenatide improved spatial memory in the MWM and increased activation of the insulin signaling pathway that resulted in increased phosphorylation at inhibitory Ser9 of GSK-3 $\beta$, the main tau protein kinase, thereby decreasing phosphorylation of the tau protein at different epitopes (Chen et al. 2012).

Several other potent and long-lasting GLP-1 analogs, including lixisenatide (Cai et al. 2014, McClean \& Holscher 2014b) and Val(8)GLP-1 (Gengler et al. 2012, Li et al. 2012, McGovern et al. 2012), which can also be palmitoylated (Lennox et al. 2013), were shown to display neuroprotective properties in in vivo experiments; the neuroprotective effects included beneficial effects on synaptic plasticity, spatial memory, and $\mathrm{A} \beta$ plaque reduction (Table 1 ).

Of the stable GIP analogs, the analog in which L-Ala ${ }^{2}$ is substitute by D-Ala has been most studied in models of neurodegeneration. After acute or chronic administration, D-Ala ${ }^{2}$-GIP showed a beneficial effect on hippocampal synaptic plasticity in C57BL mice (Faivre et al. 2012), improved impaired neuronal synaptic plasticity and LTP in DIO mice (Porter et al. 2011); it also reduced blood glucose levels. D-Ala²-GIP was administered to APP/PS1 mice for 21 days when the animals were 6 and 12 months (Faivre \& Holscher 2013b) or 19 months of age (Faivre $\&$ Holscher 2013a). At all ages, the treatment resulted in increased synaptic plasticity, reduced neuroinflammation and reduced numbers of $A \beta$ plaques. At the age of 12 months, D-Ala2 ${ }^{2}$ GIP improved memory in the novel object recognition test and the MWM (Table 1).

Recently, drugs targeting additional receptors have been designed with increased anti-diabetic properties. These include dual agonists of GLP-1/GIP receptors and a triple agonist of GLP-1/GIP/glucagon receptors (Finan et al. 2015, Holscher 2018). One of the GLP-1/GIP analogs, DA-JC4 (Shi et al. 2017b), and the triple agonist (Tai et al. 2018) were also examined for potential neuroprotective properties. Both molecules improved spatial memory in the MWM and Y-maze tests and reduced neuroinflammation as manifested by decreased levels of reactive astrocytes and activated microglia using Iba-1 staining. Moreover, administration of DA-JC4 for two weeks to rats that had received ICV injection of STZ resulted in increased phosphorylation of tau protein, ameliorated the activation of kinases implicated in the insulin signaling pathway, including IRS1 and Akt, and attenuated tau hyperphosphorylation at several epitopes (Shi et al. 2017b). The triple agonist was administered to

(c) 2019 Society for Endocrinology Published by Bioscientifica Ltd. Printed in Great Britain
APP/PS1 mice for two months; it reduced the numbers of $\mathrm{A} \beta$ plaques and increased the level of the synaptic marker synaptophysin and of doublecortin, a marker of neurogenesis (Tai et al. 2018). Both analogs seem to be potent neuroprotective compounds (Shi et al. 2017b, Tai et al. 2018) (Table 1).

\section{Conclusion and future direction}

This review summarizes the findings about the possible role of anorexigenic peptides in experimental models of $\mathrm{AD}$ pathology. Undoubtedly, the pathogenesis of $\mathrm{AD}$ is a complicated process involving both genetic and environmental factors. Despite extensive studies and a lot of promising results, further studies are needed to understand the precise role of food intake regulating peptides in pathogenesis of AD. However, this is not simple because studies using highly selected clinical samples from patients with autosomal dominant AD suggest that the neuropathology of $\mathrm{AD}$ begins to develop decades before the onset of symptoms or detectable deficits (Fleisher $\mathrm{et} \mathrm{al}$. 2015). Moreover, conditions in utero may influence the risk of age-related diseases through epigenetic changes (Maloney \& Lahiri 2016, Doehner et al. 2017). Because the preclinical phase of $\mathrm{AD}$ development has such a broad developmental window, it is very difficult to precisely specify the timeframe in which prevention must begin to be most effective. Other problem is that no experimental model precisely represents pathology of human AD; thus, comparison of several different animal models together could bring the light to the pathological processes of human $\mathrm{AD}$.

If one accepts the hypothesis that $\mathrm{AD}$ is associated with impaired glucose metabolism and insulin and leptin resistance in the brain, it is reasonable to assume that improvement of these disorders can prevent $\mathrm{AD}$. We and others have clearly demonstrated that peripherally administered anorexigenic peptides can improve systemic glucose resistance in obese animals (Maletinska et al. 2015, Holscher 2018, Mikulaskova et al. 2018) and that these compounds positively affect learning and memory (Fig. 2). The key role of insulin and leptin was demonstrated and neuropeptides positively regulated by insulin and leptin were shown to have neuroprotective effects with respect to AD pathology. In addition to their role in the regulation of food intake, also other food intake regulating hormones (e.g. melanocortins, CART peptide, PrRP, amylin or GLP-1 analogs), which are released both peripherally and centrally and act centrally, were recently 
proposed to function also as growth factors that stimulate cell growth and cell repair in neurons (Holscher 2018), to restore insulin signaling pathways in brain areas associated with learning and memory formation, and thus to positively influence spatial memory (Mandal et al. 2018) in animal studies. Like insulin and leptin, they can also modulate the insulin/leptin signaling pathway, thereby acting as neuroprotective hormones (Yarchoan \& Arnold 2014), improving hippocampal synaptic plasticity and enhancing cognitive performance (Fadel et al. 2013). It was also shown especially that stable incretin GLP-1 analogs can be used to prevent neurodegenerative processes and improve neuronal and synaptic functionality in models of $\mathrm{AD}$ and PD and also in first clinical trials (Holscher 2014).

Thus, these studies support the idea that some neuropeptides might have the potential to improve neurodegeneration and thereby improve and/or slow down AD. However, many other studies are needed to understand the precise mechanisms of $\mathrm{AD}$ pathology, to find at least approximate developmental window for the onset of the disease and finally, to find potential drugs for the $\mathrm{AD}$ treatment.

\section{Declaration of interest}

The authors declare that there is no conflict of interest that could be perceived as prejudicing the impartiality of this review.

\section{Funding}

This work was supported by the Grant agency of the Czech Republic No. 16-00918S and by the Academy of Sciences of the Czech Republic RVO: 61388963 and RVO: 67985823.

\section{References}

Abe T, Koga N, Tomita M, Tonoike T, Kushima M, Takahashi K, Sano Y \& Taniyama M 2003 Cellular localization of prolactin-releasing peptide receptors in the human pituitary. Acta Neuropathologica 106 495-500. (https://doi.org/10.1007/s00401-003-0753-7)

Adler BL, Yarchoan M, Hwang HM, Louneva N, Blair JA, Palm R, Smith MA, Lee HG, Arnold SE \& Casadesus G 2014 Neuroprotective effects of the amylin analogue pramlintide on Alzheimer's disease pathogenesis and cognition. Neurobiology of Aging 35 793-801. (https://doi.org/10.1016/j.neurobiolaging.2013.10.076)

Ahima RS, Bjorbaek C, Osei S \& Flier JS 1999 Regulation of neuronal and glial proteins by leptin: implications for brain development. Endocrinology 140 2755-2762. (https://doi.org/10.1210/ endo.140.6.6774)

Ahrens VM, Bellmann-Sickert K \& Beck-Sickinger AG 2012 Peptides and peptide conjugates: therapeutics on the upward path. Future Medicinal Chemistry 4 1567-1586. (https://doi.org/10.4155/fmc.12.76)

Akiguchi I, Pallas M, Budka H, Akiyama H, Ueno M, Han J, Yagi H, Nishikawa T, Chiba Y, Sugiyama H, et al. 2017 SAMP8 mice as a neuropathological model of accelerated brain aging and dementia: Toshio Takeda's legacy and future directions. Neuropathology 37 293-305. (https://doi.org/10.1111/neup.12373)

Andermann ML \& Lowell BB 2017 Toward a wiring diagram understanding of appetite control. Neuron 95 757-778. (https://doi. org/10.1016/j.neuron.2017.06.014)

Barker DJ, Hales CN, Fall CH, Osmond C, Phipps K \& Clark PM 1993 Type 2 (non-insulin-dependent) diabetes mellitus, hypertension and hyperlipidaemia (syndrome $\mathrm{X}$ ): relation to reduced fetal growth. Diabetologia 36 62-67. (https://doi.org/10.1007/BF00399095)

Batista AF, Forny-Germano L, Clarke JR, Lyra E, Silva NM, Brito-Moreira J, Boehnke SE, Winterborn A, Coe BC, Lablans A, Vital JF, et al. 2018 The diabetes drug liraglutide reverses cognitive impairment in mice and attenuates insulin receptor and synaptic pathology in a nonhuman primate model of Alzheimer's disease. Journal of Pathology 245 85-100. (https://doi.org/10.1002/path.5056)

Beck B \& Pourie G 2013 Ghrelin, neuropeptide Y, and other feedingregulatory peptides active in the hippocampus: role in learning and memory. Nutrition Reviews 71 541-561. (https://doi.org/10.1111/ nure.12045)

Bezprozvanny IB 2010 Calcium signaling and neurodegeneration. Acta Naturae 2 72-82.

Bharadwaj P, Wijesekara N, Liyanapathirana M, Newsholme P, Ittner L, Fraser P \& Verdile G 2017 The link between type 2 diabetes and neurodegeneration: roles for amyloid-beta, amylin, and tau proteins Journal of Alzheimers Disease 59 421-432. (https://doi.org/10.3233/ JAD-161192)

Blennow K, Dubois B, Fagan AM, Lewczuk P, de Leon MJ \& Hampel H 2015 Clinical utility of cerebrospinal fluid biomarkers in the diagnosis of early Alzheimer's disease. Alzheimer's and Dementia 11 58-69. (https://doi.org/10.1016/j.jalz.2014.02.004)

Bogdanovic N, Davidsson P, Volkmann I, Winblad B \& Blennow K 2000 Growth-associated protein GAP-43 in the frontal cortex and in the hippocampus in Alzheimer's disease: an immunohistochemical and quantitative study. Journal of Neural Transmission 107 463-478. (https://doi.org/10.1007/s007020070088)

Bomfim TR, Forny-Germano L, Sathler LB, Brito-Moreira J, Houzel JC, Decker H, Silverman MA, Kazi H, Melo HM, McClean PL, et al. 2012 An anti-diabetes agent protects the mouse brain from defective insulin signaling caused by Alzheimer's disease-associated Abeta oligomers. Journal of Clinical Investigation 122 1339-1353. (https://doi. org/10.1172/JCI57256)

Bonda DJ, Stone JG, Torres SL, Siedlak SL, Perry G, Kryscio R, Jicha G, Casadesus G, Smith MA, Zhu X, et al. 2014 Dysregulation of leptin signaling in Alzheimer disease: evidence for neuronal leptin resistance. Journal of Neurochemistry 128 162-172. (https://doi. org/10.1111/jnc.12380)

Boyle RG, Downham R, Ganguly T, Humphries J, Smith J \& Travers S 2005 Structure-activity studies on prolactin-releasing peptide (PrRP). Analogues of PrRP-(19-31)-peptide. Journal of Peptide Science 11 161-165. (https://doi.org/10.1002/psc.612)

Butterfield DA, Di Domenico F \& Barone E 2014 Elevated risk of type 2 diabetes for development of Alzheimer disease: a key role for oxidative stress in brain. Biochimica et Biophysica Acta 1842 1693-1706. (https://doi.org/10.1016/j.bbadis.2014.06.010)

Cai HY, Holscher C, Yue XH, Zhang SX, Wang XH, Qiao F, Yang W \& Qi JS 2014 Lixisenatide rescues spatial memory and synaptic plasticity from amyloid beta protein-induced impairments in rats. Neuroscience 277 6-13. (https://doi.org/10.1016/j.neuroscience.2014.02.022)

Cai HY, Wang ZJ, Hölscher C, Yuan L, Zhang J, Sun P, Li J, Yang W, Wu MN \& Qi JS 2017 Lixisenatide attenuates the detrimental effects of amyloid beta protein on spatial working memory and hippocampal neurons in rats. Behavioural Brain Research 318 28-35. (https://doi. org/10.1016/j.bbr.2016.10.033)

Cao Y, Hölscher C, Hu MM, Wang T, Zhao F, Bai Y, Zhang J, Wu MN \& Qi JS 2018 DA5-CH, a novel GLP-1/GIP dual agonist, 
effectively ameliorates the cognitive impairments and pathology in the APP/PS1 mouse model of Alzheimer's disease. European Journal of Pharmacology 827 215-226. (https://doi.org/10.1016/j. ejphar.2018.03.024)

Casaletto KB, Elahi FM, Bettcher BM, Neuhaus J, Bendlin BB, Asthana S, Johnson SC, Yaffe K, Carlsson C, Blennow K, et al. 2017 Neurogranin, a synaptic protein, is associated with memory independent of Alzheimer biomarkers. Neurology 89 1782-1788. (https://doi. org/10.1212/WNL.0000000000004569)

Cavanaugh SE, Pippin JJ \& Barnard ND 2014 Animal models of Alzheimer disease: historical pitfalls and a path forward. ALTEX 31 279-302. (https://doi.org/10.14573/altex.1310071)

Chen S, Liu AR, An FM, Yao WB \& Gao XD 2012 Amelioration of neurodegenerative changes in cellular and rat models of diabetesrelated Alzheimer's disease by exendin-4. Age 34 1211-1224. (https:// doi.org/10.1007/s11357-011-9303-8)

Chiba T, Yamada M, Sasabe J, Terashita K, Shimoda M, Matsuoka M \& Aiso S 2009 Amyloid-beta causes memory impairment by disturbing the JAK2/STAT3 axis in hippocampal neurons. Molecular Psychiatry 14 206-222. (https://doi.org/10.1038/mp.2008.105)

Cholerton B, Baker LD \& Craft S 2011 Insulin resistance and pathological brain ageing. Diabetic Medicine 28 1463-1475. (https://doi. org/10.1111/j.1464-5491.2011.03464.x)

Collingridge GL, Isaac JT \& Wang YT 2004 Receptor trafficking and synaptic plasticity. Nature Reviews Neuroscience 5 952-962. (https:// doi.org/10.1038/nrn1556)

Crews L, Rockenstein E \& Masliah E 2010 APP transgenic modeling of Alzheimer's disease: mechanisms of neurodegeneration and aberrant neurogenesis. Brain Structure and Function 214 111-126. (https://doi. org/10.1007/s00429-009-0232-6)

Cui H, Lopez M \& Rahmouni K 2017 The cellular and molecular bases of leptin and ghrelin resistance in obesity. Nature Reviews Endocrinology 13 338-351. (https://doi.org/10.1038/nrendo.2016.222)

Cummings JL 2011 Biomarkers in Alzheimer's disease drug development. Alzheimer's and Dementia 7 e13-e44.

Cummings JL, Vinters HV, Cole GM \& Khachaturian ZS 1998 Alzheimer's disease: etiologies, pathophysiology, cognitive reserve, and treatment opportunities. Neurology 51 S2-S17; discussion S65-S17. (https://doi. org/10.1212/WNL.51.1_Suppl_1.S2)

Curiati PK, Magaldi RM, Suemoto CK, Bottino CM, Nitrini R, Farfel JM \& Jacob-Filho W 2014 Vascular risk as a predictor of cognitive decline in a cohort of elderly patients with mild to moderate dementia. Dementia and Geriatric Cognitive Disorders Extra 4 402-409. (https:// doi.org/10.1159/000368190)

de Candia P \& Matarese G 2018 Leptin and ghrelin: sewing metabolism onto neurodegeneration. Neuropharmacology 136 307-316. (https:// doi.org/10.1016/j.neuropharm.2017.12.025)

de la Monte SM 2014 Type 3 diabetes is sporadic Alzheimers disease: mini-review. European Neuropsychopharmacology 24 1954-1960. (https://doi.org/10.1016/j.euroneuro.2014.06.008)

de la Monte SM, Ng SC \& Hsu DW 1995 Aberrant GAP-43 gene expression in Alzheimer's disease. American Journal of Pathology 147 934-946.

de la Monte SM, Tong M, Lester-Coll N, Plater M Jr \& Wands JR 2006 Therapeutic rescue of neurodegeneration in experimental type 3 diabetes: relevance to Alzheimer's disease. Journal of Alzheimer's Disease 10 89-109.

Delporte C 2013 Structure and physiological actions of ghrelin. Scientifica 2013 518909. (https://doi.org/10.1155/2013/518909)

Diano S, Farr SA, Benoit SC, McNay EC, da Silva I, Horvath B, Gaskin FS, Nonaka N, Jaeger LB, Banks WA, et al. 2006 Ghrelin controls hippocampal spine synapse density and memory performance. Nature Neuroscience 9 381-388. (https://doi.org/10.1038/nn1656)

Dineley KT, Jahrling JB \& Denner L 2014 Insulin resistance in Alzheimer's disease. Neurobiology of Disease 72 92-103. (https://doi.org/10.1016/j. nbd.2014.09.001)
Doehner W, Prasse L, Wolpers J, Bruckner MK, Ueberham U \& Arendt T 2017 Transgenerational transmission of an anticholinergic endophenotype with memory dysfunction. Neurobiology of Aging $\mathbf{5 1}$ 19-30. (https://doi.org/10.1016/j.neurobiolaging.2016.11.016)

Doherty GH, Beccano-Kelly D, Yan SD, Gunn-Moore FJ \& Harvey J 2013 Leptin prevents hippocampal synaptic disruption and neuronal cell death induced by amyloid beta. Neurobiology of Aging 34 226-237. (https://doi.org/10.1016/j.neurobiolaging.2012.08.003)

Domise M, Didier S, Marinangeli C, Zhao H, Chandakkar P, Buée L, Viollet B, Davies P, Marambaud P \& Vingtdeux V 2016 AMP-activated protein kinase modulates tau phosphorylation and tau pathology in vivo. Scientific Reports 6 26758. (https://doi.org/10.1038/srep26758)

Donev R, Kolev M, Millet B \& Thome J 2009 Neuronal death in Alzheimer's disease and therapeutic opportunities. Journal of Cellular and Molecular Medicine 13 4329-4348. (https://doi.org/10.1111/j.15824934.2009.00889.x)

Drucker DJ 2006 The biology of incretin hormones. Cell Metabolism 3 153-165. (https://doi.org/10.1016/j.cmet.2006.01.004)

Dujardin S, Colin M \& Buee L 2015 Invited review: animal models of tauopathies and their implications for research/translation into the clinic. Neuropathology and Applied Neurobiology 41 59-80. (https://doi. org/10.1111/nan.12200)

Dziennis S \& Alkayed NJ 2008 Role of signal transducer and activator of transcription 3 in neuronal survival and regeneration. Reviews in the Neurosciences 19 341-361. (https://doi.org/10.1515/ REVNEURO.2008.19.4-5.341)

El Khoury NB, Gratuze M, Petry F, Papon M-A, Julien C, Marcouiller F, Morin F, Nicholls SB, Calon F, Hébert SS, et al. 2016 Hypothermia mediates age-dependent increase of tau phosphorylation in $\mathrm{db} / \mathrm{db}$ mice. Neurobiology of Disease 88 55-65. (https://doi.org/10.1016/j. nbd.2016.01.005)

Eslami M, Sadeghi B \& Goshadrou F 2018 Chronic ghrelin administration restores hippocampal long-term potentiation and ameliorates memory impairment in rat model of Alzheimer's disease. Hippocampus 28 724-734. (https://doi.org/10.1002/hipo.23002)

Fadel JR, Jolivalt CG \& Reagan LP 2013 Food for thought: the role of appetitive peptides in age-related cognitive decline. Ageing Research Reviews 12 764-776. (https://doi.org/10.1016/j.arr.2013.01.009)

Faivre E \& Holscher C 2013a D-Ala2GIP facilitated synaptic plasticity and reduces plaque load in aged wild type mice and in an Alzheimer's disease mouse model. Journal of Alzheimer's Disease 35 267-283. (https://doi.org/10.3233/JAD-121888)

Faivre E \& Holscher C 2013b Neuroprotective effects of D-Ala2GIP on Alzheimer's disease biomarkers in an APP/PS1 mouse model. Alzheimer's Research and Therapy 5 20. (https://doi.org/10.1186/ alzrt174)

Faivre E \& Hoelscher C 2013c Neuroprotective effects of D-Ala(2)GIP on Alzheimer's disease biomarkers in an APP/PS1 mouse model. Alzheimer's Research and Therapy 5 article ID 20. (https://doi. org/10.1186/alzrt174)

Faivre E, Hamilton A \& Holscher C 2012 Effects of acute and chronic administration of GIP analogues on cognition, synaptic plasticity and neurogenesis in mice. European Journal of Pharmacology 674 294-306. (https://doi.org/10.1016/j.ejphar.2011.11.007)

Farr SA, Banks WA \& Morley JE 2006 Effects of leptin on memory processing. Peptides 27 1420-1425. (https://doi.org/10.1016/j. peptides.2005.10.006)

Farris W, Mansourian S, Chang Y, Lindsley L, Eckman EA, Frosch MP, Eckman CB, Tanzi RE, Selkoe DJ \& Guenette S 2003 Insulin-degrading enzyme regulates the levels of insulin, amyloid beta-protein, and the beta-amyloid precursor protein intracellular domain in vivo. PNAS 100 4162-4167. (https://doi.org/10.1073/pnas.0230450100)

Fernandez-Martos CM, Atkinson RAK, Chuah MI, King AE \& Vickers JC 2017 Combination treatment with leptin and pioglitazone in a mouse model of Alzheimer's disease. Alzheimer's and Dementia 3 92-106. (https://doi.org/10.1016/j.trci.2016.11.002) 
Ferreira ST, Clarke JR, Bomfim TR \& De Felice FG 2014 Inflammation, defective insulin signaling, and neuronal dysfunction in Alzheimer's disease. Alzheimer's and Dementia 10 S76-S83. (https://doi org/10.1016/j.jalz.2013.12.010)

Ferri CP, Prince M, Brayne C, Brodaty H, Fratiglioni L, Ganguli M, Hall K, Hasegawa K, Hendrie H, Huang Y, et al. 2005 Global prevalence of dementia: a Delphi consensus study. Lancet 366 2112-2117. (https:// doi.org/10.1016/S0140-6736(05)67889-0)

Finan B, Yang B, Ottaway N, Smiley DL, Ma T, Clemmensen C, Chabenne J, Zhang L, Habegger KM, Fischer K, et al. 2015 A rationally designed monomeric peptide triagonist corrects obesity and diabetes in rodents. Nature Medicine 21 27-36. (https://doi.org/10.1038/ nm.3761)

Fleisher AS, Chen K, Quiroz YT, Jakimovich LJ, Gutierrez Gomez M, Langois CM, Langbaum JB, Roontiva A, Thiyyagura P, Lee W, et al. 2015 Associations between biomarkers and age in the presenilin 1 E280A autosomal dominant Alzheimer disease kindred: a crosssectional study. JAMA Neurology 72 316-324. (https://doi.org/10.1001/ jamaneurol.2014.3314)

Forner S, Baglietto-Vargas D, Martini AC, Trujillo-Estrada L \& LaFerla FM 2017 Synaptic impairment in Alzheimer's disease: a dysregulated symphony. Trends in Neurosciences 40 347-357. (https://doi. org/10.1016/j.tins.2017.04.002)

Frago LM \& Chowen JA 2015 Hypothalamic leptin and ghrelin signaling as targets for improvement in metabolic control. Current Pharmaceutical Design 21 3596-3605. (https://doi.org/10.2174/138161 2821666150710145428)

Friend DM, Devarakonda K, O’Neal TJ, Skirzewski M, Papazoglou I, Kaplan AR, Liow JS, Guo J, Rane SG, Rubinstein M, et al. 2017 Basal ganglia dysfunction contributes to physical inactivity in obesity. Cell Metabolism 25 312-321. (https://doi.org/10.1016/j.cmet.2016.12.001)

Garza JC, Guo M, Zhang W \& Lu XY 2008 Leptin increases adult hippocampal neurogenesis in vivo and in vitro. Journal of Biological Chemistry 283 18238-18247. (https://doi.org/10.1074/jbc. M800053200)

Gengler S, McClean PL, McCurtin R, Gault VA \& Holscher C 2012 Val(8) GLP-1 rescues synaptic plasticity and reduces dense core plaques in APP/PS1 mice. Neurobiology of Aging 33 265-276. (https://doi. org/10.1016/j.neurobiolaging.2010.02.014)

Ghasemi R, Zarifkar A, Rastegar K, maghsoudi N \& Moosavi M 2014 Insulin protects against Abeta-induced spatial memory impairment, hippocampal apoptosis and MAPKs signaling disruption. Neuropharmacology 85 113-120. (https://doi.org/10.1016/j. neuropharm.2014.01.036)

Giuliani D, Bitto A, Galantucci M, Zaffe D, Ottani A, Irrera N, Neri L, Cavallini GM, Altavilla D, Botticelli AR, et al. 2014a Melanocortins protect against progression of Alzheimer's disease in tripletransgenic mice by targeting multiple pathophysiological pathways. Neurobiology of Aging 35 537-547. (https://doi.org/10.1016/j. neurobiolaging.2013.08.030)

Giuliani D, Galantucci M, Neri L, Canalini F, Calevro A, Bitto A, Ottani A, Vandini E, Sena P, Sandrini M, et al. 2014b Melanocortins protect against brain damage and counteract cognitive decline in a transgenic mouse model of moderate Alzheimers disease. European Journal of Pharmacology 740 144-150. (https://doi.org/10.1016/j. ejphar.2014.06.063)

Giuliani D, Neri L, Canalini F, Calevro A, Ottani A, Vandini E, Sena P, Zaffe D \& Guarini S 2015 NDP-alpha-MSH induces intense neurogenesis and cognitive recovery in Alzheimer transgenic mice through activation of melanocortin MC4 receptors. Molecular and Cellular Neurosciences 67 13-21. (https://doi.org/10.1016/j. mcn.2015.05.004)

Giuliani D, Ottani A, Neri L, Zaffe D, Grieco P, Jochem J, Cavallini GM, Catania A \& Guarini S 2017 Multiple beneficial effects of melanocortin MC4 receptor agonists in experimental neurodegenerative disorders: therapeutic perspectives.
Progress in Neurobiology 148 40-56. (https://doi.org/10.1016/j. pneurobio.2016.11.004)

Gotz J, Deters N, Doldissen A, Bokhari L, Ke Y, Wiesner A, Schonrock N \& Ittner LM 2007 A decade of tau transgenic animal models and beyond. Brain Pathology 17 91-103. (https://doi.org/10.1111/j.17503639.2007.00051.x)

Graham WV, Bonito-Oliva A \& Sakmar TP 2017 Update on Alzheimer's disease therapy and prevention strategies. Annual Review of Medicine 68 413-430. (https://doi.org/10.1146/annurevmed-042915-103753)

Greco SJ, Sarkar S, Casadesus G, Zhu X, Smith MA, Ashford JW, Johnston JM \& Tezapsidis N 2009 Leptin inhibits glycogen synthase kinase-3 beta to prevent tau phosphorylation in neuronal cells. Neuroscience Letters 455 191-194. (https://doi.org/10.1016/j.neulet.2009.03.066)

Greco SJ, Bryan KJ, Sarkar S, Zhu X, Smith MA, Ashford JW, Johnston JM, Tezapsidis N \& Casadesus G 2010 Leptin reduces pathology and improves memory in a transgenic mouse model of Alzheimer's disease. Journal of Alzheimer's Disease 19 1155-1167. (https://doi. org/10.3233/JAD-2010-1308)

Grundke-Iqbal I, Iqbal K, Quinlan M, Tung YC, Zaidi MS \& Wisniewski HM 1986 Microtubule-associated protein tau. A component of Alzheimer paired helical filaments. Journal of Biological Chemistry 261 6084-6089.

Guillot F, Kemppainen S, Lavasseur G, Miettinen PO, Laroche S, Tanila H \& Davis S 2016 Brain-specific basal and novelty-induced alternations in PI3K-Akt and MAPK/ERK signaling in a middle-aged AbetaPP/PS1 mouse model of Alzheimer's disease. Journal of Alzheimers Disease $\mathbf{5 1}$ 1157-1173. (https://doi.org/10.3233/JAD-150926)

Han WN, Hölscher C, Yuan L, Yang W, Wang XH, Wu MN \& Qi JS 2013 Liraglutide protects against amyloid-beta protein-induced impairment of spatial learning and memory in rats. Neurobiology of Aging $\mathbf{3 4}$ 576-588. (https://doi.org/10.1016/j.neurobiolaging.2012.04.009)

Hansen HH, Fabricius K, Barkholt P, Niehoff ML, Morley JE, Jelsing J, Pyke C, Bjerre Knudsen L, Farr SA \& Vrang N 2015 The GLP-1 receptor agonist liraglutide improves memory function and increases hippocampal CA1 neuronal numbers in a senescence-accelerated mouse model of Alzheimer's disease. Journal of Alzheimers Disease $\mathbf{4 6}$ 877-888. (https://doi.org/10.3233/JAD-143090)

Harrison FE, Hosseini AH \& McDonald MP 2009 Endogenous anxiety and stress responses in water maze and Barnes maze spatial memory tasks. Behavioural Brain Research 198 247-251. (https://doi.org/10.1016/j. bbr.2008.10.015)

Harvey J, Solovyova N \& Irving A 2006 Leptin and its role in hippocampal synaptic plasticity. Progress in Lipid Research 45 369-378. (https://doi.org/10.1016/j.plipres.2006.03.001)

Hauss-Wegrzyniak B, Dobrzanski P, Stoehr JD \& Wenk GL 1998 Chronic neuroinflammation in rats reproduces components of the neurobiology of Alzheimer's disease. Brain Research 780 294-303. (https://doi.org/10.1016/S0006-8993(97)01215-8)

Heneka MT, Carson MJ, El Khoury J, Landreth GE, Brosseron F, Feinstein DL, Jacobs AH, Wyss-Coray T, Vitorica J, Ransohoff RM, et al. 2015 Neuroinflammation in Alzheimer's disease. Lancet Neurology 14 388-405. (https://doi.org/10.1016/S14744422(15)70016-5)

Hinuma S, Habata Y, Fujii R, Kawamata Y, Hosoya M, Fukusumi S, Kitada C, Masuo Y, Asano T, Matsumoto H, et al. 1998 A prolactinreleasing peptide in the brain. Nature 393 272-276. (https://doi. org/10.1038/30515)

Hochgrafe K, Sydow A \& Mandelkow EM 2013 Regulatable transgenic mouse models of Alzheimer disease: onset, reversibility and spreading of tau pathology. FEBS Journal 280 4371-4381. (https://doi. org/10.1111/febs.12250)

Hol EM \& Pekny M 2015 Glial fibrillary acidic protein (GFAP) and the astrocyte intermediate filament system in diseases of the central nervous system. Current Opinion in Cell Biology 32 121-130. (https:// doi.org/10.1016/j.ceb.2015.02.004) 
Holden KF, Lindquist K, Tylavsky FA, Rosano C, Harris TB, Yaffe K \& Health ABC Study 2009 Serum leptin level and cognition in the elderly: findings from the Health ABC Study. Neurobiology of Aging $\mathbf{3 0}$ 1483-1489. (https://doi.org/10.1016/j.neurobiolaging.2007.11.024)

Holscher C 2014 New drug treatments show neuroprotective effects in Alzheimer's and Parkinson's diseases. Neural Regeneration Research 9 1870-1873. (https://doi.org/10.4103/1673-5374.145342)

Holscher C 2018 Novel dual GLP-1/GIP receptor agonists show neuroprotective effects in Alzheimer's and Parkinson's disease models. Neuropharmacology 136 251-259. (https://doi.org/10.1016/j. neuropharm.2018.01.040)

Holubova M, Blechova M, Kakonova A, Kunes J, Zelezna B \& Maletinska L 2018 In vitro and in vivo characterization of novel stable peptidic ghrelin analogs: beneficial effects in the settings of lipopolysaccharideinduced anorexia in mice. Journal of Pharmacology and Experimental Therapeutics 366 422-432. (https://doi.org/10.1124/jpet.118.249086)

Humpel C 2011 Identifying and validating biomarkers for Alzheimer's disease. Trends in Biotechnology 29 26-32. (https://doi.org/10.1016/j. tibtech.2010.09.007)

Irving AJ \& Harvey J 2014 Leptin regulation of hippocampal synaptic function in health and disease. Philosophical Transactions of the Royal Society of London: Series B, Biological Sciences 369 20130155. (https:// doi.org/10.1098/rstb.2013.0155)

Jankowsky JL \& Zheng H 2017 Practical considerations for choosing a mouse model of Alzheimer's disease. Molecular Neurodegeneration 12 89. (https://doi.org/10.1186/s13024-017-0231-7)

Jensen PB, Kristensen P, Clausen JT, Judge ME, Hastrup S, Thim L, Wulff BS, Foged C, Jensen J, Holst JJ, et al. 1999 The hypothalamic satiety peptide CART is expressed in anorectic and non-anorectic pancreatic islet tumors and in the normal islet of Langerhans. FEBS Letters $\mathbf{4 4 7}$ 139-143. (https://doi.org/10.1016/S0014-5793(99)00291-4)

Jeong YO, Shin SJ, Park JY, Ku BK, Song JS, Kim JJ, Jeon SG, Lee SM \& Moon M 2018 MK-0677, a ghrelin agonist, alleviates amyloid betarelated pathology in 5XFAD mice, an animal model of Alzheimer's disease. International Journal of Molecular Sciences 19 E1800. (https:// doi.org/10.3390/ijms19061800)

Jicha GA, Weaver C, Lane E, Vianna C, Kress Y, Rockwood J \& Davies P 1999 cAMP-dependent protein kinase phosphorylations on tau in Alzheimer's disease. Journal of Neuroscience 19 7486-7494. (https://doi. org/10.1523/JNEUROSCI.19-17-07486.1999)

Jin JL, Liou AK, Shi Y, Yin KL, Chen L, Li LL, Zhu XL, Qian L, Yang R, Chen J, et al. 2015 CART treatment improves memory and synaptic structure in APP/PS1 mice. Scientific Reports 5 10224. (https://doi. org/10.1038/srep10224)

Kaya I, Brinet D, Michno W, Baskurt M, Zetterberg H, Blenow K \& Hanrieder J 2017 Novel trimodal MALDI imaging mass spectrometry (IMS3) at 10 mum reveals spatial lipid and peptide correlates implicated in Abeta plaque pathology in Alzheimer's disease. ACS Chemical Neuroscience 8 2778-2790. (https://doi.org/10.1021/ acschemneuro.7b00314)

Kelly P, McClean PL, Ackermann M, Konerding MA, Hölscher C \& Mitchell CA 2015 Restoration of cerebral and systemic microvascular architecture in APP/PS1 transgenic mice following treatment with Liraglutide ${ }^{\mathrm{TM}}$. Microcirculation 22 133-145. (https://doi.org/10.1111/ micc.12186)

Kim B \& Feldman EL 2015 Insulin resistance as a key link for the increased risk of cognitive impairment in the metabolic syndrome. Experimental and Molecular Medicine 47 e149. (https://doi.org/10.1038/ emm.2015.3)

King A, Brain A, Hanson K, Dittmann J, Vickers J \& Fernandez-Martos C 2018 Disruption of leptin signalling in a mouse model of Alzheimer's disease. Metabolic Brain Disease 33 1097-1110. (https://doi. org/10.1007/s11011-018-0203-9)

Kojima M, Hosoda H, Date Y, Nakazato M, Matsuo H \& Kangawa K 1999 Ghrelin is a growth-hormone-releasing acylated peptide from stomach. Nature $\mathbf{4 0 2}$ 656-660. (https://doi.org/10.1038/45230)
Kreiner G 2018 What have we learned recently from transgenic mouse models about neurodegeneration? The most promising discoveries of this millennium. Pharmacological Reports 70 1105-1115. (https://doi. org/10.1016/j.pharep.2018.09.006)

Kunes J, Prazienkova V, Popelova A, Mikulaskova B, Zemenova J \& Maletinska L 2016 Prolactin-releasing peptide: a new tool for obesity treatment. Journal of Endocrinology 230 R51-R58. (https://doi. org/10.1530/JOE-16-0046)

Lara VP, Caramelli P, Teixeira AL, Barbosa MT, Carmona KC, Carvalho MG, Fernandes AP \& Gomes KB 2013 High cortisol levels are associated with cognitive impairment no-dementia (CIND) and dementia. Clinica Chimica Acta; International Journal of Clinical Chemistry 423 18-22. (https://doi.org/10.1016/j.cca.2013.04.013)

Lau J \& Herzog H 2014 CART in the regulation of appetite and energy homeostasis. Frontiers in Neuroscience 8 313. (https://doi.org/10.3389/ fnins.2014.00313)

Lawrence CB, Celsi F, Brennand J \& Luckman SM 2000 Alternative role for prolactin-releasing peptide in the regulation of food intake. Nature Neuroscience 3 645-646. (https://doi.org/10.1038/76597)

Lee G \& Leugers CJ 2012 Tau and tauopathies. Progress in Molecular Biology and Translational Science 107 263-293.

Lennox R, Porter DW, Flatt PR \& Gault VA 2013 (Val(8))GLP-1-GluPAL: a GLP-1 agonist that improves hippocampal neurogenesis, glucose homeostasis, and beta-cell function in high-fat-fed mice. ChemMedChem 8 595-602. (https://doi.org/10.1002/cmdc.201200409)

Lennox R, Porter DW, Flatt PR, Holscher C, Irwin N \& Gault VA 2014 Comparison of the independent and combined effects of sub-chronic therapy with metformin and a stable GLP-1 receptor agonist on cognitive function, hippocampal synaptic plasticity and metabolic control in high-fat fed mice. Neuropharmacology 86 22-30. (https:// doi.org/10.1016/j.neuropharm.2014.06.026)

Li L \& Holscher C 2007 Common pathological processes in Alzheimer disease and type 2 diabetes: a review. Brain Research Reviews 56 384-402. (https://doi.org/10.1016/j.brainresrev.2007.09.001)

Li XL, Aou S, Oomura Y, Hori N, Fukunaga K \& Hori T 2002 Impairment of long-term potentiation and spatial memory in leptin receptordeficient rodents. Neuroscience 113 607-615. (https://doi.org/10.1016/ S0306-4522(02)00162-8)

Li Y, Duffy KB, Ottinger MA, Ray B, Bailey JA, Holloway HW, Tweedie D, Perry T, Mattson MP, Kapogiannis D, et al. 2010 GLP-1 receptor stimulation reduces amyloid-beta peptide accumulation and cytotoxicity in cellular and animal models of Alzheimer's disease. Journal of Alzheimer's Disease 19 1205-1219. (https://doi.org/10.3233/ JAD-2010-1314)

Li L, Zhang ZF, Holscher C, Gao C, Jiang YH \& Liu YZ 2012 (Val(8)) glucagon-like peptide-1 prevents tau hyperphosphorylation, impairment of spatial learning and ultra-structural cellular damage induced by streptozotocin in rat brains. European Journal of Pharmacology 674 280-286. (https://doi.org/10.1016/j. ejphar.2011.11.005)

Li H, Wu J, Zhu L, Sha L, Yang S, Wei J, Ji L, Tang X, Mao K, Cao L, et al. 2018 Insulin degrading enzyme contributes to the pathology in a mixed model of Type 2 diabetes and Alzheimer's disease: possible mechanisms of IDE in T2D and AD. Bioscience Reports $\mathbf{3 8}$ BSR20170862. (https://doi.org/10.1042/BSR20170862)

Lieb W, Beiser AS, Vasan RS, Tan ZS, Au R, Harris TB, Roubenoff R, Auerbach S, DeCarli C, Wolf PA, et al. 2009 Association of plasma leptin levels with incident Alzheimer disease and MRI measures of brain aging. JAMA 302 2565-2572. (https://doi.org/10.1001/ jama.2009.1836)

Lin S \& Huang XF 1997 Fasting increases leptin receptor mRNA expression in lean but not obese (ob/ob) mouse brain. NeuroReport 8 3625-3629.

Lindwall G \& Cole RD 1984 Phosphorylation affects the ability of Tau protein to promote microtubule assembly. Journal of Biological Chemistry 259 5301-5305. 
Liu Y, Liu F, Grundke-Iqbal I, Iqbal K \& Gong CX 2011 Deficient brain insulin signalling pathway in Alzheimer's disease and diabetes. Journal of Pathology 225 54-62. (https://doi.org/10.1002/path.2912)

Liu C, Feng X, Li Q, Wang Y, Li Q \& Hua M 2016 Adiponectin, TNFalpha and inflammatory cytokines and risk of type 2 diabetes: a systematic review and meta-analysis. Cytokine 86 100-109. (https:// doi.org/10.1016/j.cyto.2016.06.028)

Long-Smith CM, Manning S, McClean PL, Coakley MF, O'Halloran DJ, Holscher C \& O'Neill C 2013 The diabetes drug Liraglutide ameliorates aberrant insulin receptor localisation and signalling in parallel with decreasing both amyloid-beta plaque and glial pathology in a mouse model of Alzheimer's disease. Neuromolecular Medicine $\mathbf{1 5}$ 102-114. (https://doi.org/10.1007/s12017-012-8199-5)

Ma K \& McLaurin J 2014 Alpha-melanocyte stimulating hormone prevents GABAergic neuronal loss and improves cognitive function in Alzheimer's disease. Journal of Neuroscience 34 6736-6745. (https://doi. org/10.1523/JNEUROSCI.5075-13.2014)

Ma T, Du X, Pick JE, Sui G, Brownlee M \& Klann E 2012 Glucagon-like peptide-1 cleavage product GLP-1(9-36) amide rescues synaptic plasticity and memory deficits in Alzheimer's disease model mice. Journal of Neuroscience 32 13701-13708. (https://doi.org/10.1523/ JNEUROSCI.2107-12.2012)

Malavolta L \& Cabral FR 2011 Peptides: important tools for the treatment of central nervous system disorders. Neuropeptides 45 309-316. (https://doi.org/10.1016/j.npep.2011.03.001)

Maletinska L, Maixnerova J, Matyskova R, Haugvicova R, Sloncova E, Elbert T, Slaninova J \& Zelezna B 2007 Cocaine- and amphetamineregulated transcript (CART) peptide specific binding in pheochromocytoma cells PC12. European Journal of Pharmacology 559 109-114. (https://doi.org/10.1016/j.ejphar.2006.12.014)

Maletinska L, Spolcova A, Maixnerova J, Blechova M \& Zelezna B 2011 Biological properties of prolactin-releasing peptide analogs with a modified aromatic ring of a C-terminal phenylalanine amide. Peptides 32 1887-1892. (https://doi.org/10.1016/j.peptides.2011.08.011)

Maletinska L, Nagelova V, Ticha A, Zemenova J, Pirnik Z, Holubova M, Spolcova A, Mikulaskova B, Blechova M, Sykora D, et al. 2015 Novel lipidized analogs of prolactin-releasing peptide have prolonged halflives and exert anti-obesity effects after peripheral administration. International Journal of Obesity 39 986-993. (https://doi.org/10.1038/ ijo.2015.28)

Maloney B \& Lahiri DK 2016 Epigenetics of dementia: understanding the disease as a transformation rather than a state. Lancet Neurology $\mathbf{1 5}$ 760-774. (https://doi.org/10.1016/S1474-4422(16)00065-X)

Mandal A, Prabhavalkar KS \& Bhatt LK 2018 Gastrointestinal hormones in regulation of memory. Peptides $\mathbf{1 0 2} 16-25$. (https://doi. org/10.1016/j.peptides.2018.02.003)

Maruyama M, Matsumoto H, Fujiwara K, Kitada C, Hinuma S, Onda H, Fujino M \& Inoue K 1999 Immunocytochemical localization of prolactin-releasing peptide in the rat brain. Endocrinology $\mathbf{1 4 0}$ 2326-2333. (https://doi.org/10.1210/endo.140.5.6685)

Matysková R, Maletínská L, Maixnerová J, Pirník Z, Kiss A \& Zelezná B 2008 Comparison of the obesity phenotypes related to monosodium glutamate effect on arcuate nucleus and/or the high fat diet feeding in C57BL/6 and NMRI mice. Physiological Research 57 727-734.

McClean PL \& Holscher C 2014a Liraglutide can reverse memory impairment, synaptic loss and reduce plaque load in aged APP/PS1 mice, a model of Alzheimer's disease. Neuropharmacology 76 57-67. (https://doi.org/10.1016/j.neuropharm.2013.08.005)

McClean PL \& Holscher C $2014 b$ Lixisenatide, a drug developed to treat type 2 diabetes, shows neuroprotective effects in a mouse model of Alzheimer's disease. Neuropharmacology 86 241-258. (https://doi. org/10.1016/j.neuropharm.2014.07.015)

McClean PL, Gault VA, Harriott P \& Hölscher C 2010 Glucagon-like peptide- 1 analogues enhance synaptic plasticity in the brain: a link between diabetes and Alzheimer's disease. European Journal of Pharmacology 630 1-3. (https://doi.org/10.1016/j.ejphar.2009.12.023)
McClean PL, Parthsarathy V, Faivre E \& Holscher C 2011 The diabetes drug liraglutide prevents degenerative processes in a mouse model of Alzheimer's disease. Journal of Neuroscience 31 6587-6594. (https://doi. org/10.1523/JNEUROSCI.0529-11.2011)

McClean PL, Jalewa J \& Holscher C 2015 Prophylactic liraglutide treatment prevents amyloid plaque deposition, chronic inflammation and memory impairment in APP/PS1 mice. Behavioural Brain Research 293 96-106. (https://doi.org/10.1016/j.bbr.2015.07.024)

McGovern SF, Hunter K \& Holscher C 2012 Effects of the glucagonlike polypeptide-1 analogue (Val8)GLP-1 on learning, progenitor cell proliferation and neurogenesis in the $\mathrm{C} 57 \mathrm{~B} / 16$ mouse brain. Brain Research 1473 204-213. (https://doi.org/10.1016/j. brainres.2012.07.029)

McGregor G \& Harvey J 2017 Leptin regulation of synaptic function at hippocampal TA-CA1 and SC-CA1 synapses: implications for health and disease. Neurochemical Research [epub]. (https://doi.org/10.1007/ s11064-017-2362-1)

Mikulaskova B, Holubova M, Prazienkova V, Zemenova J, Hruba L, Haluzik M, Zelezna B, Kunes J \& Maletinska L 2018 Lipidized prolactin-releasing peptide improved glucose tolerance in metabolic syndrome: koletsky and spontaneously hypertensive rat study. Nutrition and Diabetes 8 5. (https://doi.org/10.1038/s41387-0170015-8)

Morley JE, Farr SA, Kumar VB \& Armbrecht HJ 2012 The SAMP8 mouse: a model to develop therapeutic interventions for Alzheimer's disease. Current Pharmaceutical Design 18 1123-1130. (https://doi. org/10.2174/138161212799315795)

Morrison CD, White CL, Wang Z, Lee SY, Lawrence DS, Cefalu WT, Zhang ZY \& Gettys TW 2007 Increased hypothalamic protein tyrosine phosphatase $1 \mathrm{~B}$ contributes to leptin resistance with age. Endocrinology 148 433-440. (https://doi.org/10.1210/en.2006-0672)

Moult PR \& Harvey J 2011 NMDA receptor subunit composition determines the polarity of leptin-induced synaptic plasticity. Neuropharmacology 61 924-936. (https://doi.org/10.1016/j. neuropharm.2011.06.021)

Moult PR, Cross A, Santos SD, Carvalho AL, Lindsay Y, Connolly CN, Irving AJ, Leslie NR \& Harvey J 2010 Leptin regulates AMPA receptor trafficking via PTEN inhibition. Journal of Neuroscience 30 4088-4101. (https://doi.org/10.1523/JNEUROSCI.3614-09.2010)

Mu Y \& Gage FH 2011 Adult hippocampal neurogenesis and its role in Alzheimer's disease. Molecular Neurodegeneration 6 85. (https://doi. org/10.1186/1750-1326-6-85)

Nagelová V, Pirník Z, Železná B \& Maletínská L 2014 CART (cocaine- and amphetamine-regulated transcript) peptide specific binding sites in PC12 cells have characteristics of CART peptide receptors. Brain Research 1547 16-24. (https://doi.org/10.1016/j. brainres.2013.12.024)

Nitrini R, Bottino CM, Albala C, Custodio Capunay NS, Ketzoian C, Llibre Rodriguez JJ, Maestre GE, Ramos-Cerqueira AT \& Caramelli P 2009 Prevalence of dementia in Latin America: a collaborative study of population-based cohorts. International Psychogeriatrics 21 622-630. (https://doi.org/10.1017/S1041610209009430)

Numakawa T, Odaka H \& Adachi N 2017 Actions of brain-derived neurotrophic factor and glucocorticoid stress in neurogenesis. International Journal of Molecular Sciences 18 E2312. (https://doi. org/10.3390/ijms18112312)

Osborn LM, Kamphuis W, Wadman WJ \& Hol EM 2016 Astrogliosis: an integral player in the pathogenesis of Alzheimer's disease. Progress in Neurobiology 144 121-141. (https://doi.org/10.1016/j. pneurobio.2016.01.001)

Palmqvist S, Zetterberg H, Mattsson N \& Johansson P. Alzheimer's Disease Neuroimaging Initiative, Minthon L, Blennow K, Olsson M, Hansson O \& Swedish Bio FSG 2015 Detailed comparison of amyloid PET and CSF biomarkers for identifying early Alzheimer disease. Neurology 85 1240-1249. (https://doi.org/10.1212/ WNL.0000000000001991) 
Park SA 2011 A common pathogenic mechanism linking type-2 diabetes and Alzheimer's disease: evidence from animal models. Journal of Clinical Neurology 7 10-18. (https://doi.org/10.3988/jcn.2011.7.1.10)

Parthsarathy V \& Holscher C 2013 Chronic treatment with the GLP1 analogue liraglutide increases cell proliferation and differentiation into neurons in an AD mouse model. PLOS ONE 8 e58784. (https:// doi.org/10.1371/journal.pone.0058784)

Pedros I, Petrov D, Artiach G, Abad S, Ramon-Duaso C, Sureda F, Pallas M, Beas-Zarate C, Folch J \& Camins A 2015 Adipokine pathways are altered in hippocampus of an experimental mouse model of Alzheimer's disease. Journal of Nutrition, Health and Aging 19 403-412. (https://doi.org/10.1007/s12603-014-0574-5)

Peralta S, Carrascosa JM, Gallardo N, Ros M \& Arribas C 2002 Ageing increases SOCS-3 expression in rat hypothalamus: effects of food restriction. Biochemical and Biophysical Research Communications 296 425-428. (https://doi.org/10.1016/S0006-291X(02)00906-3)

Pérez-González R, Antequera D, Vargas T, Spuch C, Bolós M \& Carro E 2011 Leptin induces proliferation of neuronal progenitors and neuroprotection in a mouse model of Alzheimer's disease. Journal of Alzheimer's Disease 24 (Supplement 2) 17-25. (https://doi. org/10.3233/JAD-2011-102070)

Platt TL, Beckett TL, Kohler K, Niedowicz DM \& Murphy MP 2016 Obesity, diabetes, and leptin resistance promote tau pathology in a mouse model of disease. Neuroscience 315 162-174. (https://doi. org/10.1016/j.neuroscience.2015.12.011)

Pomytkin I, Costa-Nunes JP, Kasatkin V, Veniaminova E, Demchenko A, Lyundup A, Lesch KP, Ponomarev ED \& Strekalova T 2018 Insulin receptor in the brain: mechanisms of activation and the role in the CNS pathology and treatment. CNS Neuroscience and Therapeutics 24 763-774. (https://doi.org/10.1111/cns.12866)

Pooler AM, Noble W \& Hanger DP 2014 A role for tau at the synapse in Alzheimer's disease pathogenesis. Neuropharmacology 76 1-8. (https:// doi.org/10.1016/j.neuropharm.2013.09.018)

Popelova A, Prazienkova V, Neprasova B, Kasperova BJ, Hruba L, Holubova M, Zemenova J, Blum D, Zelezna B, Galas MC, et al. 2018 Novel lipidized analog of prolactin-releasing peptide improves memory impairment and attenuates hyperphosphorylation of Tau protein in a mouse model of tauopathy. Journal of Alzheimer's Disease 62 1725-1736. (https://doi.org/10.3233/JAD-17104)

Porter DW, Kerr BD, Flatt PR, Holscher C \& Gault VA 2010 Four weeks administration of liraglutide improves memory and learning as well as glycaemic control in mice with high fat dietary-induced obesity and insulin resistance. Diabetes, Obesity and Metabolism 12 891-899. (https://doi.org/10.1111/j.1463-1326.2010.01259.x)

Porter DW, Irwin N, Flatt PR, Holscher C \& Gault VA 2011 Prolonged GIP receptor activation improves cognitive function, hippocampal synaptic plasticity and glucose homeostasis in high-fat fed mice. European Journal of Pharmacology 650 688-693. (https://doi. org/10.1016/j.ejphar.2010.10.059)

Porter D, Faivre E, Flatt PR, Hölscher C \& Gault VA 2012 Actions of incretin metabolites on locomotor activity, cognitive function and in vivo hippocampal synaptic plasticity in high fat fed mice. Peptides 35 1-8. (https://doi.org/10.1016/j.peptides.2012.03.014)

Porter WD, Flatt PR, Holscher C \& Gault VA 2013 Liraglutide improves hippocampal synaptic plasticity associated with increased expression of Mash1 in ob/ob mice. International Journal of Obesity 37 678-684. (https://doi.org/10.1038/ijo.2012.91)

Prazienkova V, Holubova M, Pelantova H, Buganova M, Pirnik Z, Mikulaskova B, Popelova A, Blechova M, Haluzik M, Zelezna B, et al. 2017 Impact of novel palmitoylated prolactin-releasing peptide analogs on metabolic changes in mice with diet-induced obesity. PLoS ONE 12 e0183449. (https://doi.org/10.1371/journal.pone.0183449)

Price DL, Wong PC, Markowska AL, Lee MK, Thinakaren G, Cleveland DW, Sisodia SS \& Borchelt DR 2000 The value of transgenic models for the study of neurodegenerative diseases.
Annals of the New York Academy of Sciences 920 179-191. (https://doi. org/10.1111/j.1749-6632.2000.tb06920.x)

Priller C, Bauer T, Mitteregger G, Krebs B, Kretzschmar HA \& Herms J 2006 Synapse formation and function is modulated by the amyloid precursor protein. Journal of Neuroscience 26 7212-7221. (https://doi. org/10.1523/JNEUROSCI.1450-06.2006)

Prinz P \& Stengel A 2017 Control of food intake by gastrointestinal peptides: mechanisms of action and possible modulation in the treatment of obesity. Journal of Neurogastroenterology and Motility 23 180-196. (https://doi.org/10.5056/jnm16194)

Procaccini C, Santopaolo M, Faicchia D, Colamatteo A, Formisano L, de Candia P, Galgani M, De Rosa V \& Matarese G 2016 Role of metabolism in neurodegenerative disorders. Metabolism: Clinical and Experimental 65 1376-1390. (https://doi.org/10.1016/j. metabol.2016.05.018)

Pugazhenthi S, Qin L \& Reddy PH 2017 Common neurodegenerative pathways in obesity, diabetes, and Alzheimer's disease. Biochimica et Biophysica Acta: Molecular Basis of Disease 1863 1037-1045. (https:// doi.org/10.1016/j.bbadis.2016.04.017)

Qi L, Ke L, Liu X, Liao L, Ke S, Liu X, Wang Y, Lin X, Zhou Y, Wu L, et al. 2016 Subcutaneous administration of liraglutide ameliorates learning and memory impairment by modulating tau hyperphosphorylation via the glycogen synthase kinase-3beta pathway in an amyloid beta protein induced Alzheimer disease mouse model. European Journal of Pharmacology 783 23-32. (https://doi.org/10.1016/j. ejphar.2016.04.052)

Qi L, Chen Z, Wang Y, Liu X, Liu X, Ke L, Zheng Z, Lin X, Zhou Y, Wu L, et al. 2017 Subcutaneous liraglutide ameliorates methylglyoxalinduced Alzheimer-like tau pathology and cognitive impairment by modulating tau hyperphosphorylation and glycogen synthase kinase3beta. American Journal of Translational Research 9 247-260.

Raffaitin C, Gin H, Empana JP, Helmer C, Berr C, Tzourio C, Portet F, Dartigues JF, Alperovitch A \& Barberger-Gateau P 2009 Metabolic syndrome and risk for incident Alzheimer's disease or vascular dementia: the three-City Study. Diabetes Care 32 169-174. (https:// doi.org/10.2337/dc08-0272)

Razay G, Vreugdenhil A \& Wilcock G 2007 The metabolic syndrome and Alzheimer disease. Archives of Neurology 64 93-96. (https://doi. org/10.1001/archneur.64.1.93)

Reddy AP \& Reddy PH 2017 Mitochondria-targeted molecules as potential drugs to treat patients with Alzheimer's disease. Progress in Molecular Biology and Translational Science 146 173-201. (https://doi. org/10.1016/bs.pmbts.2016.12.010)

Ricci G, Pirillo I, Tomassoni D, Sirignano A \& Grappasonni I 2017 Metabolic syndrome, hypertension, and nervous system injury: Epidemiological correlates. Clinical and Experimental Hypertension 39 8-16. (https://doi.org/10.1080/10641963.2016.1210629)

Rodriguez JJ \& Verkhratsky A 2011 Neurogenesis in Alzheimer's disease. Journal of Anatomy 219 78-89. (https://doi.org/10.1111/j.14697580.2011.01343.x)

Rogge G, Jones D, Hubert GW, Lin Y \& Kuhar MJ 2008 CART peptides: regulators of body weight, reward and other functions. Nature Reviews Neuroscience 9 747-758. (https://doi.org/10.1038/nrn2493)

Rowan MJ, Klyubin I, Cullen WK \& Anwyl R 2003 Synaptic plasticity in animal models of early Alzheimer's disease. Philosophical Transactions of the Royal Society of London: Series B, Biological Sciences 358 821-828. (https://doi.org/10.1098/rstb.2002.1240)

Samson WK, Resch ZT, Murphy TC \& Chang JK 1998 Gender-biased activity of the novel prolactin releasing peptides: comparison with thyrotropin releasing hormone reveals only pharmacologic effects. Endocrine 9 289-291. (https://doi.org/10.1385/ ENDO:9:3:289)

Santos VV, Stark R, Rial D, Silva HB, Bayliss JA, Lemus MB, Davies JS, Cunha RA, Prediger RD \& Andrews ZB 2017 Acyl ghrelin improves cognition, synaptic plasticity deficits and neuroinflammation https://joe.bioscientifica.com https://doi.org/10.1530/JOE-18-0532 (c) 2019 Society for Endocrinology Published by Bioscientifica Ltd. Printed in Great Britain 
following amyloid beta (Abeta1-40) administration in mice. Journal of Neuroendocrinology 29 [epub]. (https://doi.org/10.1111/jne.12546)

Scarpace PJ, Matheny M, Moore RL \& Tumer N 2000 Impaired leptin responsiveness in aged rats. Diabetes 49 431-435. (https://doi. org/10.2337/diabetes.49.3.431)

Scharfman H, Goodman J, Macleod A, Phani S, Antonelli C \& Croll S 2005 Increased neurogenesis and the ectopic granule cells after intrahippocampal BDNF infusion in adult rats. Experimental Neurology 192 348-356. (https://doi.org/10.1016/j.expneurol.2004.11.016)

Scheltens P, Blennow K, Breteler MM, de Strooper B, Frisoni GB, Salloway S \& Van der Flier WM 2016 Alzheimer's disease. Lancet 388 505-517. (https://doi.org/10.1016/S0140-6736(15)01124-1)

Schindowski K, Bretteville A, Leroy K, Begard S, Brion JP, Hamdane M \& Buee L 2006 Alzheimer's disease-like tau neuropathology leads to memory deficits and loss of functional synapses in a novel mutated tau transgenic mouse without any motor deficits. American Journal of Pathology 169 599-616. (https://doi.org/10.2353/ ajpath.2006.060002)

Schioth HB, Craft S, Brooks SJ, Frey WH, 2nd \& Benedict C 2012 Brain insulin signaling and Alzheimer's disease: current evidence and future directions. Molecular Neurobiology 46 4-10. (https://doi.org/10.1007/ s12035-011-8229-6)

Schwartz MW, Woods SC, Porte D Jr, Seeley RJ \& Baskin DG 2000 Central nervous system control of food intake. Nature $\mathbf{4 0 4} 661-671$. (https:// doi.org/10.1038/35007534)

Shanley LJ, Irving AJ \& Harvey J 2001 Leptin enhances NMDA receptor function and modulates hippocampal synaptic plasticity. Journal of Neuroscience 21 RC186. (https://doi.org/10.1523/JNEUROSCI.2124-j0001.2001)

Shanley LJ, O’Malley D, Irving AJ, Ashford ML \& Harvey J 2002 Leptin inhibits epileptiform-like activity in rat hippocampal neurones via PI 3-kinase-driven activation of BK channels. Journal of Physiology $\mathbf{5 4 5}$ 933-944. (https://doi.org/10.1113/jphysiol.2002.029488)

Shao CY, Mirra SS, Sait HB, Sacktor TC \& Sigurdsson EM 2011 Postsynaptic degeneration as revealed by PSD-95 reduction occurs after advanced Abeta and tau pathology in transgenic mouse models of Alzheimer's disease. Acta Neuropathologica 122 285-292. (https:// doi.org/10.1007/s00401-011-0843-x)

Shen Y, Tian M, Zheng Y, Gong F, Fu AKY \& Ip NY 2016 Stimulation of the hippocampal POMC/MC4R circuit alleviates synaptic plasticity impairment in an Alzheimer's disease model. Cell Reports 17 1819-1831. (https://doi.org/10.1016/j.celrep.2016.10.043)

Sheng M, Sabatini BL \& Sudhof TC 2012 Synapses and Alzheimer's disease. Cold Spring Harbor Perspectives in Biology 4 a005777. (https:// doi.org/10.1101/cshperspect.a005777)

Shi L, Du X, Jiang H \& Xie J 2017a Ghrelin and neurodegenerative disorders-a review. Molecular Neurobiology 54 1144-1155. (https://doi. org/10.1007/s12035-016-9729-1)

Shi L, Zhang Z, Li L \& Holscher C 2017b A novel dual GLP-1/GIP receptor agonist alleviates cognitive decline by re-sensitizing insulin signaling in the Alzheimer icv. STZ rat model. Behavioural Brain Research $\mathbf{3 2 7}$ 65-74. (https://doi.org/10.1016/j.bbr.2017.03.032)

Siervo M, Harrison SL, Jagger C, Robinson L \& Stephan BC 2014 Metabolic syndrome and longitudinal changes in cognitive function: a systematic review and meta-analysis. Journal of Alzheimer's Disease 41 151-161. (https://doi.org/10.3233/JAD-132279)

Skaper SD, Facci L, Zusso M \& Giusti P 2017 Synaptic plasticity, dementia and Alzheimer disease. CNS and Neurological Disorders Drug Targets 16 220-233. (https://doi.org/10.2174/1871527316666170113120853)

Sohn JW 2015 Network of hypothalamic neurons that control appetite. BMB Reports 48 229-233. (https://doi.org/10.5483/ BMBRep.2015.48.4.272)

Soudy R, Patel A, Fu W, Kaur K, MacTavish D, Westaway D, Davey R, Zajac J \& Jhamandas J 2017 Cyclic AC253, a novel amylin receptor antagonist, improves cognitive deficits in a mouse model of Alzheimer's disease. Alzheimer's and Dementia: Translational Research and Clinical Interventions 3 44-56. (https://doi.org/10.1016/j. trci.2016.11.005)

Spiegelman BM \& Flier JS 2001 Obesity and the regulation of energy balance. Cell 104 531-543. (https://doi.org/10.1016/S00928674(01)00240-9)

Spolcova A, Mikulaskova B, Krskova K, Gajdosechova L, Zorad Š, Olszanecki R, Suski M, Bujak-Gizycka B, Zelezna B \& Maletinska L 2014 Deficient hippocampal insulin signaling and augmented Tau phosphorylation is related to obesity- and age-induced peripheral insulin resistance: a study in Zucker rats. BMC Neuroscience 15111. (https://doi.org/10.1186/1471-2202-15-111)

Spolcova A, Mikulaskova B, Holubova M, Nagelova V, Pirnik Z, Zemenova J, Haluzik M, Zelezna B, Galas MC \& Maletinska L 2015 Anorexigenic lipopeptides ameliorate central insulin signaling and attenuate tau phosphorylation in hippocampi of mice with monosodium glutamate-induced obesity. Journal of Alzheimer's Disease 45 823-835. (https://doi.org/10.3233/JAD-143150)

Spuch C, Diz-Chaves Y, Pérez-Tilve D, Alvarez-Crespo M \& Mallo F 2007 Prolactin-releasing Peptide (PrRP) increases prolactin responses to TRH in vitro and in vivo. Endocrine 31 119-124. (https://doi. org/10.1007/s12020-007-0031-x)

Steen E, Terry BM, Rivera EJ, Cannon JL, Neely TR, Tavares R, Xu XJ Wands JR \& de la Monte SM 2005 Impaired insulin and insulin-like growth factor expression and signaling mechanisms in Alzheimer's disease - is this type 3 diabetes? Journal of Alzheimer's Disease 7 63-80.

Stranahan AM, Norman ED, Lee K, Cutler RG, Telljohann RS, Egan JM \& Mattson MP 2008 Diet-induced insulin resistance impairs hippocampal synaptic plasticity and cognition in middle-aged rats Hippocampus 18 1085-1088. (https://doi.org/10.1002/hipo.20470)

Tabaton M, Zhu X, Perry G, Smith MA \& Giliberto L 2010 Signaling effect of amyloid-beta(42) on the processing of AbetaPP. Experimental Neurology 221 18-25. (https://doi.org/10.1016/j. expneurol.2009.09.002)

Tai J, Liu W, Li Y, Li L \& Holscher C 2018 Neuroprotective effects of a triple GLP-1/GIP/glucagon receptor agonist in the APP/PS1 transgenic mouse model of Alzheimer's disease. Brain Research 1678 64-74. (https://doi.org/10.1016/j.brainres.2017.10.012)

Takashima A 2006 GSK-3 is essential in the pathogenesis of Alzheimer's disease. Journal of Alzheimer's Disease 9 309-317.

Takeda T, Hosokawa M, Takeshita S, Irino M, Higuchi K, Matsushita T, Tomita Y, Yasuhira K, Hamamoto H, Shimizu K, et al. 1981 A new murine model of accelerated senescence. Mechanisms of Ageing and Development 17 183-194. (https://doi.org/10.1016/00476374(81)90084-1)

Takeda S, Sato N, Uchio-Yamada K, Sawada K, Kunieda T, Takeuchi D, Kurinami H, Shinohara M, Rakugi H \& Morishita R 2010 Diabetesaccelerated memory dysfunction via cerebrovascular inflammation and Abeta deposition in an Alzheimer mouse model with diabetes. PNAS 107 7036-7041. (https://doi.org/10.1073/pnas.1000645107)

Tampellini D, Capetillo-Zarate E, Dumont M, Huang Z, Yu F, Lin MT \& Gouras GK 2010 Effects of synaptic modulation on beta-amyloid, synaptophysin, and memory performance in Alzheimer's disease transgenic mice. Journal of Neuroscience 30 14299-14304. (https://doi. org/10.1523/JNEUROSCI.3383-10.2010)

Taupin P 2007 BrdU immunohistochemistry for studying adult neurogenesis: paradigms, pitfalls, limitations, and validation Brain Research Reviews 53 198-214. (https://doi.org/10.1016/j. brainresrev.2006.08.002)

Taylor MM \& Samson WK 2001 The prolactin releasing peptides: RF-amide peptides. Cellular and Molecular Life Sciences 58 1206-1215. (https://doi.org/10.1007/PL00000934)

Terry RD, Masliah E, Salmon DP, Butters N, DeTeresa R, Hill R, Hansen LA \& Katzman R 1991 Physical basis of cognitive alterations in Alzheimer's disease: synapse loss is the major correlate of cognitive impairment. Annals of Neurology 30 572-580. (https://doi. org/10.1002/ana.410300410) 
Teter B 2009 Rodent Aging A2 - Squire, Larry R In Encyclopedia of Neuroscience, pp 397-406. Oxford: Academic Press.

Tezapsidis N, Johnston JM, Smith MA, Ashford JW, Casadesus G, Robakis NK, Wolozin B, Perry G, Zhu X, Greco SJ, et al. 2009 Leptin: a novel therapeutic strategy for Alzheimer's disease. Journal of Alzheimer's Disease 16 731-740. (https://doi.org/10.3233/jad-2009-1021)

Tong JQ, Zhang J, Hao M, Yang J, Han YF, Liu XJ, Shi H, Wu MN, Liu QS \& Qi JS 2015 Leptin attenuates the detrimental effects of betaamyloid on spatial memory and hippocampal later-phase long term potentiation in rats. Hormones and Behavior 73 125-130. (https://doi. org/10.1016/j.yhbeh.2015.06.013)

Trinchese F, Liu S, Battaglia F, Walter S, Mathews PM \& Arancio O 2004 Progressive age-related development of Alzheimer-like pathology in APP/PS1 mice. Annals of Neurology 55 801-814. (https://doi. org/10.1002/ana.20101)

Turner N \& Heilbronn LK 2008 Is mitochondrial dysfunction a cause of insulin resistance? Trends in Endocrinology and Metabolism 19 324-330. (https://doi.org/10.1016/j.tem.2008.08.001)

Turner PR, O'Connor K, Tate WP \& Abraham WC 2003 Roles of amyloid precursor protein and its fragments in regulating neural activity, plasticity and memory. Progress in Neurobiology 70 1-32. (https://doi. org/10.1016/S0301-0082(03)00089-3)

Upadhya MA, Nakhate KT, Kokare DM, Singru PS \& Subhedar NK 2011 Cocaine- and amphetamine-regulated transcript peptide increases spatial learning and memory in rats. Life Sciences 88 322-334. (https://doi.org/10.1016/j.lfs.2010.12.008)

Vagelatos NT \& Eslick GD 2013 Type 2 diabetes as a risk factor for Alzheimer's disease: the confounders, interactions, and neuropathology associated with this relationship. Epidemiologic Reviews 35 152-160. (https://doi.org/10.1093/epirev/mxs012)

van der Klaauw AA 2018 Neuropeptides in obesity and metabolic disease. Clinical Chemistry 64 173-182. (https://doi.org/10.1373/ clinchem.2017.281568)

Velazquez R, Tran A, Ishimwe E, Denner L, Dave N, Oddo S \& Dineley KT 2017 Central insulin dysregulation and energy dyshomeostasis in two mouse models of Alzheimer's disease. Neurobiology of Aging 58 1-13. (https://doi.org/10.1016/j.neurobiolaging.2017.06.003)

Vickers JC, Kirkcaldie MT, Phipps A \& King AE 2016 Alterations in neurofilaments and the transformation of the cytoskeleton in axons may provide insight into the aberrant neuronal changes of Alzheimer's disease. Brain Research Bulletin 126 324-333. (https://doi. org/10.1016/j.brainresbull.2016.07.012)

Vilsboll T \& Holst JJ 2004 Incretins, insulin secretion and type 2 diabetes mellitus. Diabetologia 47 357-366. (https://doi.org/10.1007/s00125004-1342-6)

Walker JM \& Harrison FE 2015 Shared neuropathological characteristics of obesity, type 2 diabetes and Alzheimer's disease: impacts on cognitive decline. Nutrients 7 7332-7357. (https://doi.org/10.3390/ nu7095341)

Wang XH, Li L, Hölscher C, Pan YF, Chen XR \& Qi JS 2010 Val8glucagon-like peptide-1 protects against A $\beta 1$-40-induced impairment of hippocampal late-phase long-term potentiation and spatial learning in rats. Neuroscience 170 1239-1248. (https://doi. org/10.1016/j.neuroscience.2010.08.028)

Wang X, Wang W, Li L, Perry G, Lee HG \& Zhu X 2014 Oxidative stress and mitochondrial dysfunction in Alzheimer's disease. Biochimica et Biophysica Acta 1842 1240-1247. (https://doi.org/10.1016/j. bbadis.2013.10.015)

Wang C, Chen X, Ding X, He Y, Gu C \& Zhou L 2015 Exendin-4 promotes beta cell proliferation via PI3k/Akt signalling pathway.
Cellular Physiology and Biochemistry 35 2223-2232. (https://doi. org/10.1159/000374027)

Wang E, Zhu H, Wang X, Gower AC, Wallack M, Blusztajn JK, Kowall N \& Qiu WQ 2017 Amylin treatment reduces neuroinflammation and ameliorates abnormal patterns of gene expression in the cerebral cortex of an Alzheimer's disease mouse model. Journal of Alzheimer's Disease 56 47-61. (https://doi.org/10.3233/JAD-160677)

Webster SJ, Bachstetter AD, Nelson PT, Schmitt FA \& Van Eldik LJ 2014 Using mice to model Alzheimer's dementia: an overview of the clinical disease and the preclinical behavioral changes in 10 mouse models. Frontiers in Genetics 5 88. (https://doi.org/10.3389/ fgene.2014.00088)

Weingarten MD, Lockwood AH, Hwo SY \& Kirschner MW 1975 A protein factor essential for microtubule assembly. PNAS 72 1858-1862. (https://doi.org/10.1073/pnas.72.5.1858)

Wilson JL \& Enriori PJ 2015 A talk between fat tissue, gut, pancreas and brain to control body weight. Molecular and Cellular Endocrinology $\mathbf{4 1 8}$ 108-119. (https://doi.org/10.1016/j.mce.2015.08.022)

Xie L, Helmerhorst E, Taddei K, Plewright B, Van Bronswijk W \& Martins R 2002 Alzheimer's beta-amyloid peptides compete for insulin binding to the insulin receptor. Journal of Neuroscience $\mathbf{2 2}$ RC221. (https://doi.org/10.1523/JNEUROSCI.22-10-j0001.2002)

Yang Y, Zhang J, Ma D, Zhang M, Hu S, Shao S \& Gong CX 2013 Subcutaneous administration of liraglutide ameliorates Alzheimerassociated tau hyperphosphorylation in rats with type 2 diabetes. Journal of Alzheimer's Disease 37 637-648. (https://doi.org/10.3233/ JAD-130491)

Yarchoan M \& Arnold SE 2014 Repurposing diabetes drugs for brain insulin resistance in Alzheimer disease. Diabetes 63 2253-2261. (https://doi.org/10.2337/db14-0287)

Yin K, Jin J, Zhu X, Yu L, Wang S, Qian L, Han L \& Xu Y 2017 CART modulates beta-amyloid metabolism-associated enzymes and attenuates memory deficits in APP/PS1 mice. Neurological Research 39 885-894. (https://doi.org/10.1080/01616412.2017.1348689)

Yuan A, Rao MV, Veeranna \& Nixon RA 2017 Neurofilaments and neurofilament proteins in health and disease. Cold Spring Harbor Perspectives in Biology 9 a018309. (https://doi.org/10.1101/cshperspect. a018309)

Zanchi D, Depoorter A, Egloff L, Haller S, Mahlmann L, Lang UE, Drewe J, Beglinger C, Schmidt A \& Borgwardt S 2017 The impact of gut hormones on the neural circuit of appetite and satiety: a systematic review. Neuroscience and Biobehavioral Reviews 80 457-475. (https:// doi.org/10.1016/j.neubiorev.2017.06.013)

Zeki Al Hazzouri A, Stone KL, Haan MN \& Yaffe K 2013 Leptin, mild cognitive impairment, and dementia among elderly women. Journals of Gerontology: Series A, Biological Sciences and Medical Sciences 68 175-180. (https://doi.org/10.1093/gerona/gls155)

Zhao Y \& Zhao B 2013 Oxidative stress and the pathogenesis of Alzheimer's disease. Oxidative Medicine and Cellular Longevity 2013 316523. (https://doi.org/10.1155/2013/367206)

Zhu H, Wang X, Wallack M, Li H, Carreras I, Dedeoglu A, Hur JY, Zheng $\mathrm{H}, \mathrm{Li} \mathrm{H}$, Fine R, et al. 2015 Intraperitoneal injection of the pancreatic peptide amylin potently reduces behavioral impairment and brain amyloid pathology in murine models of Alzheimer's disease. Molecular Psychiatry 20 252-262. (https://doi.org/10.1038/ $\mathrm{mp} .2014 .17)$

Zhu H, Xue X, Wang E, Wallack M, Na H, Hooker JM, Kowall N, Tao Q, Stein TD, Wolozin B, et al. 2017 Amylin receptor ligands reduce the pathological cascade of Alzheimer's disease. Neuropharmacology 119 170-181. (https://doi.org/10.1016/j.neuropharm.2017.03.030)

Received in final form 12 November 2018

Accepted 20 November 2018

Accepted Preprint published online 20 November 2018 https://joe.bioscientifica.com https://doi.org/10.1530/JOE-18-0532 (c) 2019 Society for Endocrinology Published by Bioscientifica Ltd. Printed in Great Britain 